Mahomoodally Afr J Tradit Complement Altern Med. (2014) 11(6):1-32

http://dx.doi.org/10.4314/ajtcam.v11i6.1

\title{
A QUANTITATIVE ETHNOBOTANICAL STUDY OF COMMON HERBAL REMEDIES USED AGAINST 13 HUMAN AILMENTS CATERGORIES IN MAURITIUS
}

\author{
Mohamad Fawzi Mahomoodally \\ Department of Health Sciences, Faculty of Science, University of Mauritius, Réduit, Mauritius \\ *Corresponding author: f.mahomoodally@uom.ac.mu
}

\begin{abstract}
Background and aim: Mauritius is a tropical multicultural island with a long-standing use of herbal remedies. The present ethnobotanical survey was geared towards documenting and preserving local knowledge pertaining to common medicinal plants (MP) used as therapeutic agents in Mauritius.

Methods: Interviews were conducted among local people and herbalists $(\mathrm{n}=318)$. Also, 7 quantitative ethnobotanical parameters (variety of use (VU), relative frequency of citation (RFC), informant consensus factor $\left(\mathrm{F}_{\mathrm{IC}}\right)$, fidelity level (FL), index of agreement on remedies (IAR), relative importance (RI) and cultural importance index (CII)) were calculated for MP used.

Results: A total of 87 plants belonging to 45 families were reported to be used in formulating herbal remedies among which 3 endemic plants have been documented. Mentha piperita was found to be the most used plant against gastrointestinal diseases with an RFC index of 0.55 . Holy basil (Ocimum tenuiflorum) had the highest RI value (RI=2.00), being cited for 9 different ailments. Therapeutic properties of some herbal remedies reported correlated to some extent with those of previous studies while others have open potential perspectives for further research as their chemistry and pharmacology have not been published.

Conclusion: From the information obtained, it can be suggested that the Mauritian population still relies heavily on MP for their primary health care. Nonetheless, further research is needed to investigate the possible active constituents that could be the basis of an evidence based investigation to discover new drugs.
\end{abstract}

Key words: Medicinal plants, ethnobotanical, therapeutic agents, Mauritius

\section{Introduction}

From the World Health Organisation's (WHO) perspective, approximately 4000 million people in developing countries utilize herbal remedies on a regular basis. Despite the accessibility of modern medicine in these countries, medicinal plants (MP) have remained a popular therapy, owing to the belief in their efficacy (Alzweiri et al., 2011). Recently there has been a surge of interest in herbal remedies even within developed countries where people are turning towards phytotherapy where chronic conditions are involved. There is great possibility that medicinal plants may turn out to be much more significant source of bioactive molecules that has ever been imagined for developing novel drugs (Bougel, 2007).

Currently more research is being directed towards phytochemicals resulting from their therapeutic ability towards diseases like cancer, cardiovascular diseases, diabetes, arthritis, cataract, and aging amongst others. The underlying reason that has contributed to the re-emergence of interest in bioactive phytochemicals is scientific proof acquired from well-designed epidemiological and experimental studies conducted over a decade ago. Investigations that are being carried out with plants are being geared towards their antioxidant activities and these are due to flavonoids considered responsible for not only reducing free radical formation but also for their scavenging (Srivastava and Vankar, 2012).

Indeed chemical analysis in MP especially belonging to Myrtaceae family has awakened the inquisitiveness of researchers. This is due to the fact that Eucalyptus globulus has been one of the most exploited medicinal plants and its leaves have extensively been utilised for a number of therapeutic properties as well as folkloric use (antiseptic, deodorant, cough, asthma, fevers, bronchitis, diabetes, malaria, rhinitis, tuberculosis and for treatment of wounds) (Vankar and Srivastava, 2012). Furthermore, according to the current growth rate, by the year 2020, the world population is expected to reach 11.5 billion. The drastic increase in population, insufficient supply of drugs in certain regions of the globe, unaffordable cost of treatment for common diseases, side effects of numerous allopathic drugs presently used and not to mention the development of resistance to currently used drugs for infectious diseases have inevitably turned our attention towards phytotherapy for a broad range of diseases (DMAPR, 2012). Elujoba et al. (2005) study mentioned that MP have greatly contributed to the management of diseases for instance HIV /AIDS, malaria, diabetes, sickle-cell anemia and mental disorders. An example is Illicium verum (Star anise) which serves as the industrial source of shikimic acid, a principal ingredient used to produce the antiviral drug, Tamiflu (oseltamivir phosphate) which is so far, the only existing drug that may diminish the severity of bird flu (Wang et al., 2011).

Studies carried out have documented the therapeutic effect of many MP that are utilised worldwide and hence it cannot be denied that the knowledge of medicinal plants that tribes possess is a starting point for modern science to discover new drugs (Clark, 2012). Many studies have been carried out with the view to determining MP used in different regions of the globe, all with the same aim; that of ultimately discovering novel drugs. This study was aimed at investigating some MP that are used by the Mauritian population and was accomplished through an ethnopharmacological survey. Given the dearth of documented information on MP used among the population, this work will provide an opportunity to collect, preserve and document their use. 
http://dx.doi.org/10.4314/ajtcam.v11i6.1

\section{Materials and methods \\ Study area and ethnobotanical survey}

The island of Mauritius is part of Sub-Saharan Africa and lies in the southern hemisphere in the middle of the Indian Ocean.The population comprises Indo-Mauritians, people of mixed European and African origin and Sino-Mauritians. The survey was conducted all over the island in order to gather maximum MP used as therapeutic agents. Around sixteen different towns and villages spread over 9 districts were visited.

The survey was performed using semi structure questionnaire through face to face (direct contact) interview on selected local people during the academic year 2011-2012. The questionnaire was designed after carrying out an in depth literature review of similar studies and surveys conducted in other countries. The questions included in the survey were adapted from the works of Bussmann et al. (2006), Yineger et al. (2007), Holroyd et al.(2008), Rokaya et al. (2010), Yadav et al. (2011), and Wodah et al. (2012). The questionnaire developed was anonymous, confidential and non-compulsory.

Proper data was partly collected using the participatory rural appraisal method, as the key informants also became investigators themselves, participating in interviews, informal meetings, open and group discussions, and overt observations with semi-structured questionnaires.

The questionnaire consisted of 6 sections: Section A - Participant profile: age, sex, level of education, place of residence and average monthly household income; Section B - MP used: Reasons behind the use of MP as therapeutic agents, person involved in the preparation and method of acquaintances with the plant use; section C - MP preparation: Participants were asked to elaborate on MP employed including the conditions for which they make use of these plants, the part(s) of the plant(s) used, the length of time for which the treatment is made use of, whether additives were used in the preparations to improve palatability, place and time of collection of the plant(s) for preparation, Section D - Cultural ritual: This section focused on determining whether cultural rituals were made use of by participants during the preparation or administration of MP preparation and if ever they were carried out, how they were done; Section E - Efficacy: In this part, the efficacy of MP preparations was assesed; Section F - Adverse effect: The purpose of this section was to determine whether adverse effects have been experienced by users of MP, the type of adverse effects and any action taken following an adverse effect.

Prior to face to face interview, the potential participants were given comprehensive information about the project and its major aims. They were assured that all information provided would be used only for education purposes and would be confidential. The interview was conducted in the local languange ('Creole') so as to facilitate communication to local people with low literacy. The participants were free to drop out at any time without any compulsion and almost all the conversations were recorded.

During field visits, when a MP was mentioned by the participant, where possible, the participant was encouraged to show a sample of the plant which was collected and/or photographed. The collected sample was then identified by local botanists. A local database was constructed whereby plant samples were assigned a collection number for future reference. A personal local repository database has been constructed to store primary data for future data mining and sharing.

The data obtained during the survey was cross-checked (local names/ scientific names) according to locally published books (Gurib-Fakim and Gueho, 1995; Gurib-Fakim, 2002). Scientific names of plant species were identified according to the International Plant Name Index (IPNI:

http://www.ipni.org).This documentation will fully recognize the contribution of the local people who have been using the indigenous knowledge, protection of community biodiversity and intellectual property rights, and benefits, if any comes out of the study and prior informed consent for publication of the work has been obtained during the survey. Also informants were assured that this research is not for commercial purpose, is for documentation and information dissemination on the traditional knowledge on MP."

\section{Quantitative ethnobotanical data}

The variety of use (VU) which indicates the number of different diseases that are treated with a particular species was assessed as decribed by Hajdu and Hohmann (2012).

Relative frequency of citation (RFC) shows the local importance of each species and it is given by the frequency of citation (FC, the number of informants mentioning the use of the species) divided by the total number of informants participating in the survey (N), without considering the use-categories (Tardío and Pardo-De-Santayana, 2008).

Calculation of a consensus factor $\left(\mathrm{F}_{\mathrm{IC}}\right)$ for testing homogeneity on the informant's knowledge was followed by the method provided by Trotter and Logan (1986). A consensus factor of $\mathrm{F}_{\mathrm{IC}}$ is given by: $\mathrm{F}_{\mathrm{IC}}=\mathrm{N}_{\mathrm{ur}}-\mathrm{N}_{\mathrm{t}} /\left(\mathrm{N}_{\mathrm{ur}}-1\right)$. The factor provides a range of 0 to 1 , where a high value (close to 1) is indicative of a high rate of informant consensus. $\mathrm{N}_{\mathrm{ur}}$ is the number of use-reports of informants for particular illness usage, where a use-report is a single record for use of a plant mentioned by an individual, and $\mathrm{N}_{\mathrm{t}}$ refers to the number of species utilised for a particular illness category for all informants. Thus, the disorders were classified as (Mutheeswaran et al., 2011): disease of the ear and mastoid process; disease of the respiratory system; disease of the eye and adnea; disease of the circulatory system; injury and poisons of external causes; disease of the genitourinary system; infectious and parasitic diseases; disease of the skin and subcutaneous tissue; disease of the digestive system; endocrine, nutritional and metabolic disorders; disease of the musculoskeletal system and connective tissue, disease of the neurological system and immunological problems.

Relative importance (RI) is defined by the following formula: RI = NUC + NT; where, regardless of the number of informants citing the species, NUC $=$ the number of use categories of a given species divided by the total number of use-categories of the most versatile species; NT $=$ the number of types of uses attributed to a given species divided by the total number of types of uses attributed to the most important taxon (Albuquerque et al., 2006).

To assess the importance of individual species in each group, fidelity level (Abouzid and Mohamed, 2011) and index of agreement on remedies (IAR) (Trotter and Logan, 1986) were used during data processing.

The fidelity level (FL) was used to indicate the percentage of informants claiming the use of a certain animal/plant species for the same medicinal purpose. The FL is calculated as follows: FL $(\%)=(\mathrm{Np} / \mathrm{N}) \times 100$; Where, Np: number of informants that claim use of a plant/animal species to treat a particular disease. $\mathrm{N}$ : number of informants that use the plant/ animal as medicine to treat any given disease. 
Mahomoodally Afr J Tradit Complement Altern Med. (2014) 11(6):1-32

http://dx.doi.org/10.4314/ajtcam.v11i6.1

The index of agreement on remedies (IAR) was used to assess the importance of individual species in each group (Mutheeswaran et al., 2011). IAR was calculated as follows: $\operatorname{IAR}=\left(\mathrm{n}_{\mathrm{r}}-\mathrm{n}_{\mathrm{a}} /(\mathrm{nr}-1)\right.$, where, $\mathrm{n}_{\mathrm{r}}$ : total number of citations registered for species $s, \mathrm{n}_{\mathrm{a}}:$ number of illness categories that are treated with this species. This value ranges between zero (when the number of illness categories equals the number of citations) and one (whereby all the participants agree upon the exclusive use of the species for the particular illness) (Chellappandian et al., 2012).

Culturally important species as medicines was identified by the Cultural Importance Index (CII). It is an objective index since it considers diversity of uses along with the consensus of informant. It was calculated as follows:

$$
\mathrm{CII}=\sum_{u=u_{1}}^{u_{n c}} \sum_{i=i_{1}}^{i_{n}} \frac{\mathrm{UR}_{u i}}{N}
$$

Where, NC: total number of different illness categories (of each $i$ species), UR: total number of use reports for each species, N: total number of informants. The CII index is the sum of the proportion of informants that mention each of the use-categories for a given species. The maximum value of the index equals the total number of different use-categories (NC), which would occur if all informants would mention the use of a species in all use-categories. In this case, the maximum CII value would be 2.00. This index was used to estimate the cultural significance of each plant species and to verify, in quantitative terms, to what extent each plant species is present in the popular culture and in the memory of the inhabitants in the study (Tardio and Pardo-De-Santayana, 2008).

\section{Results}

Table 1 provides demographic information (gender, age, residence, education level, and average monthly income) recorded from the 318 indigenous people who participated in the survey. Ninety six (30.2\%) males and $222(69.8 \%)$ females were recruited during the field survey, of which informants aged over 60 years were observed to have the highest $(24.5 \%)$ participation rate. Considering the literacy background, it was found that individuals having secondary education were mostly (32.1\%) involved in the study. The majority (50.9\%) of the informants' monthly income was between 10001-25000 Mauritian rupees.

Table 1: $\quad$ Socio-demographic characteristics of interviewee $(n=318)$.

\begin{tabular}{|c|c|c|c|}
\hline \multicolumn{2}{|l|}{ Background characteristics } & \multicolumn{2}{|c|}{ Frequency $(\%)$} \\
\hline \multirow[t]{2}{*}{ Gender } & Male & 96 & 30.2 \\
\hline & Female & 222 & 69.8 \\
\hline \multirow[t]{5}{*}{ Age } & $20-30$ & 72 & 22.6 \\
\hline & $31-40$ & 30 & 9.4 \\
\hline & $41-50$ & 72 & 22.6 \\
\hline & $51-60$ & 66 & 20.8 \\
\hline & $>60$ & 78 & 24.5 \\
\hline \multirow[t]{2}{*}{ Residence } & Rural & 204 & 64.2 \\
\hline & Urban & 114 & 35.8 \\
\hline \multirow[t]{5}{*}{ Level of education } & No formal education & 54 & 17.0 \\
\hline & Primary & 60 & 18.9 \\
\hline & Secondary & 102 & 32.1 \\
\hline & Tertiary & 96 & 30.2 \\
\hline & Others & 6 & 1.9 \\
\hline \multirow[t]{4}{*}{ Monthly Household income } & $<10,000$ & 72 & 22.6 \\
\hline & $10,001-25,000$ & 162 & 50.9 \\
\hline & $25,001-50,000$ & 84 & 26.4 \\
\hline & $>50,000$ & 0 & \\
\hline
\end{tabular}

$\mathrm{n}$ : number of participants.

Primary ethnobotanical information (local/vernacular name(s), parts used, source, number of citations, dosage and method of preparation, VU, RFC and RI) for all the different herbal remedies were collected from the informants and summarized in Table 2. Additionally, an endeavour has been made to cite relevant scientific reference(s) on the quoted medicinal plants. A plethora of medicinal plants are commonly used by the local people as depicted in Table 2. A total of 87 plants belonging to 45 families were reported to be used in formulating herbal remedies among which 3 endemic plants were reported to be in common use among the local people. 
Mahomoodally Afr J Tradit Complement Altern Med. (2014) 11(6):1-32

http://dx.doi.org/10.4314/ajtcam.v11i6.1

The highest RFC value (0.55) was recorded for Mentha piperita which tend to designate its preference and popularity for treating particular illnesses. The RI of the species cited by 318 informants ranged from 0.25 to 2.00 . A total of 55 plant species had RI $\leq 0.5 ; 27$ species, RI from 0.51 to 1.0; 4 species, RI from 1.01 to 1.5 , and 1 species with RI from 1.51 to 2.0. The species with RI $\geq 1.5$, was Ocimum tenuiflorum (RI= 2.00), and those with $1.01<\mathrm{RI}<1.5$ included Allium sativum $(\mathrm{RI}=1.52)$, Camellia sinensis $(\mathrm{RI}=1.13)$, Aloe vera $(\mathrm{RI}=1.13)$ and Zingiber officinale $\mathrm{Roscoe}(\mathrm{RI}=1.13)$.

Table 3: Depicts the $F_{I C}$ values for the ailments. The $F_{I C}$ values ranged from 0.80 to 1.00 with an average value of 0.93 , showing high level of agreements among the informants. Based on the $F_{I C}$ in Table 3, infectious and parasitic diseases had the highest (1.00) $F_{I C}$ value followed by disease of the genitourinary system $\left(\mathrm{F}_{\mathrm{IC}}=0.98\right)$ and immunological problems $\left(\mathrm{F}_{\mathrm{IC}}=0.97\right)$. Disease of the musculoskeletal system and connective tissue had the lowest $(0.80) \mathrm{F}_{\mathrm{IC}}$.

Table 3: Categories of Ailments and Informant Consensus Factor.

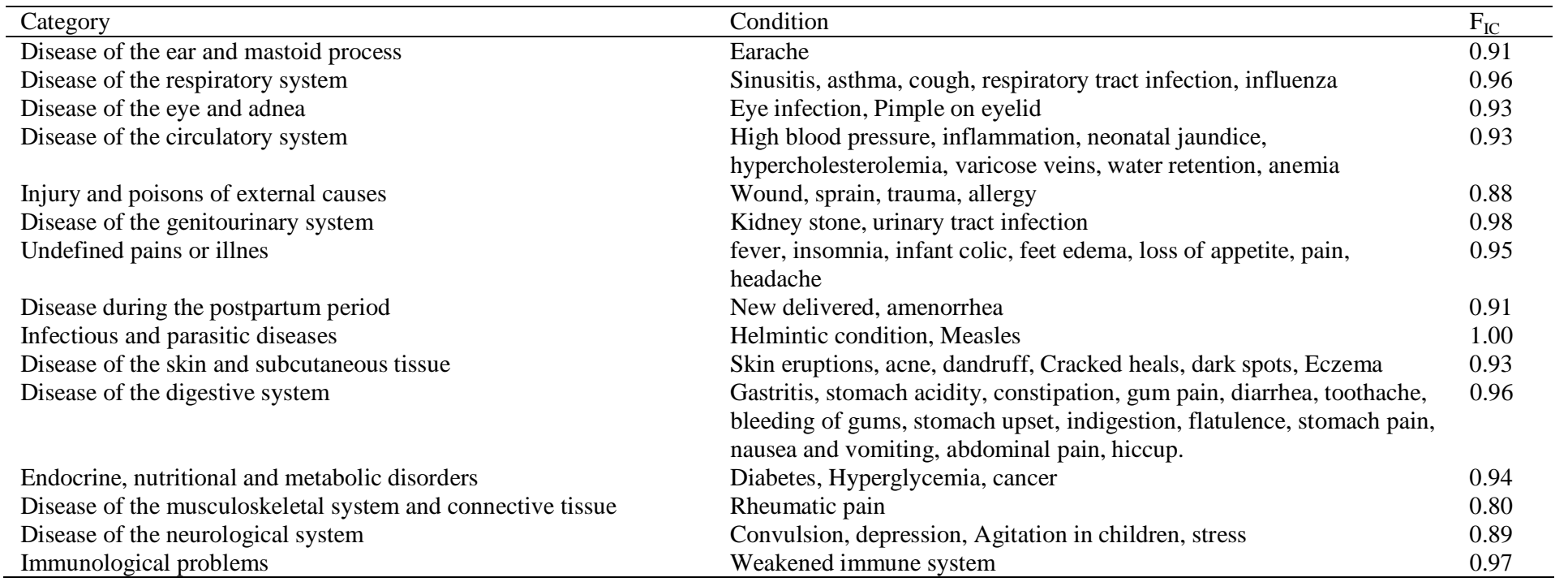

$\mathrm{N}_{\mathrm{t}}$ : Number of species used; $\mathrm{N}_{\mathrm{ur}}$ : Use citation; $\mathrm{F}_{\mathrm{IC}}$ : Informant consensus factor

As shown in Table 4, the maximum FL of 1.00 was found for 26 species. FLs for plant species for a specific disease category varied widely, ranging between 0.36 and 1.00 for plants in the study area. Furthermore, Table 3 showed that IAR values ranged from 0.88 to 1.00 . High values of IAR tend to indicate that the plants species are used for a small number of disease categories compared to those having low IAR values which is indicative of use in multiple disease categories. For instance, the lowest IAR value was for Ocimum tenuiflorum since it was used in 7 disease categories. 
Mahomoodally Afr J Tradit Complement Altern Med. (2014) 11(6):1-32

Table 2: Ethnopharmacological data relating to the 87 plants used by Mauritians.

\begin{tabular}{|c|c|c|c|c|c|c|c|}
\hline Family/Plant species & VN/CEN & Source & RFC,VU,RI & Indication & Method of preparation & $\begin{array}{l}\text { Plant part } \\
\text { used }\end{array}$ & Recorded literature use \\
\hline \multirow[t]{6}{*}{ Allium sativum Linn } & Lail/ Garlic & $\mathrm{C} / \mathrm{P}$ & $0.21,6,1.52$ & Rheumatic pain & $\begin{array}{l}\text { Crush and soak in mustard oil. } \\
\text { Apply onto the skin. }\end{array}$ & $\mathrm{Bu}$ & $\begin{array}{l}\text { Antibacterial,antiviral, } \\
\text { antiprotozoal,beneficial effect }\end{array}$ \\
\hline & & & & Helmintic condition & $\begin{array}{l}\text { Rub } 1 \text { clove of Allium sativum } \\
\text { around the navel. }\end{array}$ & & $\begin{array}{l}\text { on } \\
\text { cardiovascular and immune } \\
\text { system. }{ }^{1}\end{array}$ \\
\hline & & & & Skin eruption & $\begin{array}{l}\text { Prepare a poultice and apply } \\
\text { onto the skin. }\end{array}$ & & \\
\hline & & & & Convulsion & $\begin{array}{l}\text { Prepare a poultice and bind } \\
\text { around the wrist. }\end{array}$ & & \\
\hline & & & & Earache & $\begin{array}{l}\text { Heat Allium sativum in oil } \\
\text { instill } 1-2 \text { drops in the ear. }\end{array}$ & & \\
\hline & & & & High blood pressure & $\begin{array}{l}\text { Prepare pickle of Allium } \\
\text { sativum and Citrus limonia. } \\
\text { Eat daily with meals }\end{array}$ & & \\
\hline $\begin{array}{l}\text { Amaranthaceae } \\
\text { Spinacia oleracea Linn }\end{array}$ & $\begin{array}{l}\text { Bred epinard/ } \\
\text { Spinach }\end{array}$ & $P$ & $0.04,1,0.25$ & Inflammation & $\begin{array}{l}\text { Extract the juice and sweeten } \\
\text { with honey. }\end{array}$ & L \& St & Antioxidant ${ }^{2}$ \\
\hline \multicolumn{8}{|l|}{ Anacardiaceae } \\
\hline Mangifera indica Linn & $\begin{array}{l}\text { Mangue/ } \\
\text { Mango }\end{array}$ & $\mathrm{C} / \mathrm{P}$ & $0.23,1,0.25$ & Pimple onto eyelid & $\begin{array}{l}\text { Rub the leaves onto the } \\
\text { eyelid. }\end{array}$ & $\mathrm{L}$ & $\begin{array}{l}\text { Laxative, headache, migraine, } \\
\text { cicatrizant (internal })^{3} \text {,Anti- } \\
\text { infective. }\end{array}$ \\
\hline \multicolumn{8}{|l|}{ Annonaceae } \\
\hline Annona muricata Linn & $\begin{array}{l}\text { Corrosol/ } \\
\text { Soursop }\end{array}$ & $\mathrm{W}$ & $0.02,1,0.25$ & High blood pressure & $\begin{array}{l}\text { Prepare an infusion of the } \\
\text { leaves and drink occasionally. }\end{array}$ & $\mathrm{L}$ & $\begin{array}{l}\text { Cough, dysentery, emetic, } \\
\text { astringent, antispasmodic, } \\
\text { parasiticidal. }\end{array}$ \\
\hline $\begin{array}{l}\text { Aphloiaceae } \\
\text { Aphloia theiformis* } \\
\text { (Vahl) Benn }\end{array}$ & Fendamane & $\mathrm{W}$ & $0.02,1,0.25$ & Inflammation & $\begin{array}{l}\text { Prepare a decoction of leaves } \\
\text { and stem. Drink } 2 \text { to } 3 \text { cups } \\
\text { per day occasionally. }\end{array}$ & L \& St & Anti-infective $^{4}$ \\
\hline $\begin{array}{l}\text { Apiaceae } \\
\text { Foeniculum vulgare } \\
\text { Mill }\end{array}$ & Fenouil/ Fennel & $\mathrm{P}$ & $0.02,1,0.25$ & Stomach upset & $\begin{array}{l}\text { Prepare an infusion of the } \\
\text { seeds of Foeniculum vulgare } \\
\text { together with leaves of } \\
\text { Ocimum tenuiflorum and } \\
\text { Mentha piperita. Drink when } \\
\text { required. }\end{array}$ & $S$ & Diseases of chest, cough ${ }^{7}$ \\
\hline
\end{tabular}


Mahomoodally Afr J Tradit Complement Altern Med. (2014) 11(6):1-32

Trachyspermum ammi Jawain/ Ajwain $\mathrm{P}$

Linn

$\begin{array}{lllll}\begin{array}{l}\text { Coriandrum sativum } \\ \text { Linn }\end{array} & \begin{array}{l}\text { Cotomili/ } \\ \text { Coriander }\end{array} & \text { C/P } & 0.08,1,0.25 & \text { Indigestion } \\ \text { Daucus carota } \text { Linn } & \text { Carote/ Carrot } & \text { C/P } & 0.09,1,0.25 & \text { Neonatal jaundice }\end{array}$

Daucus carota Linn

Carote/ Carrot

$0.09,1,0.25$

Daucus carota $\mathrm{L}$ and mix

with milk in feeding bottle if

child is not being breastfed.

Alternatively, if the child is

being breastfed, then it is the

mother who takes it.

\section{Apiaceae}

Mill

Persille/

Parsley

$\mathrm{C} / \mathrm{W}$

$0.11,2,0.37$

Hypercholesterolemia

Extract the juice from the leaves and stem.Administer once weekly.

Prepare a decoction of the seeds. Drink when required.

Prepare a decoction of the seeds of Pimpinella anisum and leaves of Mentha piperita. Drink when required.

Flatulence

Prepare a decoction of

Pimpinella anisum seeds,

Eupatorium triplinerve Vahl.

leaves and Illicium verum

fruits. Drink when required.

Flatulence

Prepare a decoction of

Pimpinella anisum seeds and

Illicium verum fruits. Drink

when required.

Prepare a decoction of

Pimpinella anisum seeds,

Mentha piperita leaves and

Mllicium verum fruits. Drit
Antispasmodic, stimulant,

tonic, carminative effect,

kidney stone pain.

$\mathrm{L} \& \mathrm{St}$

Anti-anxiety activity.

Antibacterial, antifungal. ${ }^{10}$

Intestinal disorders ${ }^{11}$, anti-

inflammatory,

hepatoprotective ${ }^{12}$

Anti-spasmodic and relaxant effects ${ }^{16}$,

antioxidant, antimicrobial. ${ }^{17}$ 
Apiaceae

Pimpinella anisum

Linn

Gro anis/ Anise

$P$

$0.43,3,0.48$

Flatulence

\section{Arecaceae}

Cocos nucifera Linn

Coco/ Coconut

C

$0.05,2,0.51$

\section{Araceae}

Colocasia esculenta

(Linn) Schott

Songe blanc/

Taro

Eupatorium triplinerve Ayapana

Vahl.

$0.02,1,0.25$

C

$0.34,5,0.84$

Nausea \& vomitting

Flatulence

\section{Asteraceae}

Eupatorium triplinerve Ayapana

$0.34,5,0.84 \quad$ Indigestion
Stomach pain

Inflammation

Fever

Abdominal pain

Prepare a decoction of

Pimpinella anisum seeds,

Illicium verum fruits, Mentha

piperita leaves, Ocimum

tenuiflorum leaves and

Zingiber officinale root. Drink

when required.

Prepare a decoction of seeds. Drink till cured.

Prepare a decoction of seeds.

Drink when required.

Prepare a decoction of the root and drink 1 glass once daily.

Apply warm oil on leaf and bind it on forehead.

Prepare a decoction of the leaves. Drink as required. Prepare an infusion of the leaves together with leaves of Mentha piperita. Drink 1 cup 2 to 3 times.

Prepare a decoction of

Eupatorium triplinerve Vahl.

leaves, Pimpinella anisum

seeds and Illicium verum

fruits. Drink 1 glass when required.

Prepare an infusion of the leaves. Drink 1 glass as required.

Prepare a poultice of the

Cracked heels
Anti-spasmodic and relaxant effects ${ }^{16}$, antioxidant,

antimicrobial. ${ }^{17}$

Malaria, fever ${ }^{16}$

leaves and apply onto cracked heels. Use till cured.

Fever, high blood pressure, flu, vomiting, nausea ${ }^{20}$
Fever, high blood pressure, flu,

vomiting,

nausea $^{20}$ 
Mahomoodally Afr J Tradit Complement Altern Med. (2014) 11(6):1-32

\begin{tabular}{|c|c|c|c|c|c|c|c|}
\hline $\begin{array}{l}\text { Chamomilla recutita } \\
\text { Linn }\end{array}$ & $\begin{array}{l}\text { Camomille/ } \\
\text { Chamomile }\end{array}$ & $\mathrm{C} / \mathrm{W}$ & $0.17,3,0.98$ & $\begin{array}{l}\text { Insomnia } \\
\text { Infant colic } \\
\text { Indigestion } \\
\text { Abdominal pain } \\
\text { Sinusitis }\end{array}$ & $\begin{array}{l}\text { Prepare an infusion of the } \\
\text { flowers. Drink for } 2 \text { to } 3 \text { days } \\
\text { Prepare a decoction of the } \\
\text { flowers. Mix with baby's } \\
\text { milk for } 2 \text { to } 3 \text { days. } \\
\text { Prepare a decoction of the } \\
\text { flowers. Drink } 2 \text { to } 3 \text { times. } \\
\text { Prepare a decoction of the } \\
\text { flowers. Drink } 2 \text { to } 3 \text { times. } \\
\text { Prepare an infusion of the } \\
\text { whole plant. }\end{array}$ & $\mathrm{Fl}$ & $\begin{array}{l}\text { Depressive effect on } \\
\mathrm{CNS}^{21} \text {,spasmolytic, } \\
\text { antimicrobial and disinfective } \\
\text { properties. }^{22}\end{array}$ \\
\hline Helianthus annuus Linn & Sunflower & $\mathrm{P}$ & $0.02,1,0.25$ & $\begin{array}{l}\text { Weakened immune } \\
\text { system }\end{array}$ & $\begin{array}{l}\text { Eat the dried seeds raw twice } \\
\text { weekly. }\end{array}$ & $S$ & Antiglycative and antioxidant ${ }^{23}$ \\
\hline $\begin{array}{l}\text { Ageratum conyzoides } \\
\text { Linn }\end{array}$ & $\begin{array}{l}\text { Herb de bouc/ } \\
\text { Goat weed }\end{array}$ & $\mathrm{W}$ & $0.11,1,0.25$ & Stomach acidity & $\begin{array}{l}\text { Prepare a decoction of the } \\
\text { whole plant. }\end{array}$ & $\mathrm{W}$ & $\begin{array}{l}\text { Sleeping sickness, }{ }^{24} \text { stop } \\
\text { internal bleeding, wound } \\
\text { healing, anti- ulcer }{ }^{25}\end{array}$ \\
\hline $\begin{array}{l}\text { Asteraceae } \\
\text { Tagetes lucida Cav. }\end{array}$ & $\begin{array}{l}\text { Genda/ } \\
\text { Marigold }\end{array}$ & $\mathrm{C} / \mathrm{W}$ & $0.08,2,0.51$ & $\begin{array}{l}\text { Abdominal pain } \\
\text { Neonatal jaundice }\end{array}$ & $\begin{array}{l}\text { Prepare a decoction of the } \\
\text { flowers. Drink } 1 \text { glass as } \\
\text { required } \\
\text { Prepare a decoction of } \\
\text { Tagetes lucida } \mathrm{L} \text { and } \\
\text { administer } 1 \text { glass to } \\
\text { breastfeeding mother. }\end{array}$ & & Inflammation, conjunctivitis. ${ }^{26}$ \\
\hline $\begin{array}{l}\text { Cynara cardunculus } \\
\text { var. scolymus }\end{array}$ & $\begin{array}{l}\text { Artichaut/ } \\
\text { Artichoke }\end{array}$ & $\mathrm{P}$ & $0.23,2,0.51$ & $\begin{array}{l}\text { Inflammation } \\
\text { Flatulence }\end{array}$ & $\begin{array}{l}\text { Prepare an infusion of the } \\
\text { leaves. Drink twice. } \\
\text { Prepare a decoction of the } \\
\text { leaves. Drink once. } \\
\text { Eat raw. }\end{array}$ & $\mathrm{L}$ & Antioxidant $^{27}$ \\
\hline $\begin{array}{l}\text { Brassicaceae } \\
\text { Brassica rapa Linn }\end{array}$ & Rave/ Turnip & $\mathrm{P}$ & $0.08,1,0.51$ & Flatulence & $\begin{array}{l}\text { Extract the juice from the fruit } \\
\text { and sweeten with honey. } \\
\text { Administer for } 2 \text { to } 3 \text { days till } \\
\text { symptoms subside. } \\
\text { Eat raw. }\end{array}$ & $\mathrm{F}$ & $\begin{array}{l}\text { Antioxidant, antimicrobial } \\
\text { properties }^{28}\end{array}$ \\
\hline $\begin{array}{l}\text { Nasturtium officinale } \\
\text { W.T Aiton }\end{array}$ & $\begin{array}{l}\text { Cresson/ } \\
\text { Watercress }\end{array}$ & $\mathrm{P}$ & $0.06,1,0.25$ & $\begin{array}{l}\text { Cough } \\
\text { Cough }\end{array}$ & $\begin{array}{l}\text { Extract the juice and mix with } \\
\text { cow's ghee. Administer for } 2 \\
\text { to } 3 \text { days. } \\
\text { Extract the juice from the } \\
\text { stem of Nasturtium officinale } \\
\text { and from the fruit of Citrus } \\
\text { aurantiifolia as well then } \\
\text { sweeten with honey. }\end{array}$ & & \\
\hline
\end{tabular}


Mahomoodally Afr J Tradit Complement Altern Med. (2014) 11(6):1-32

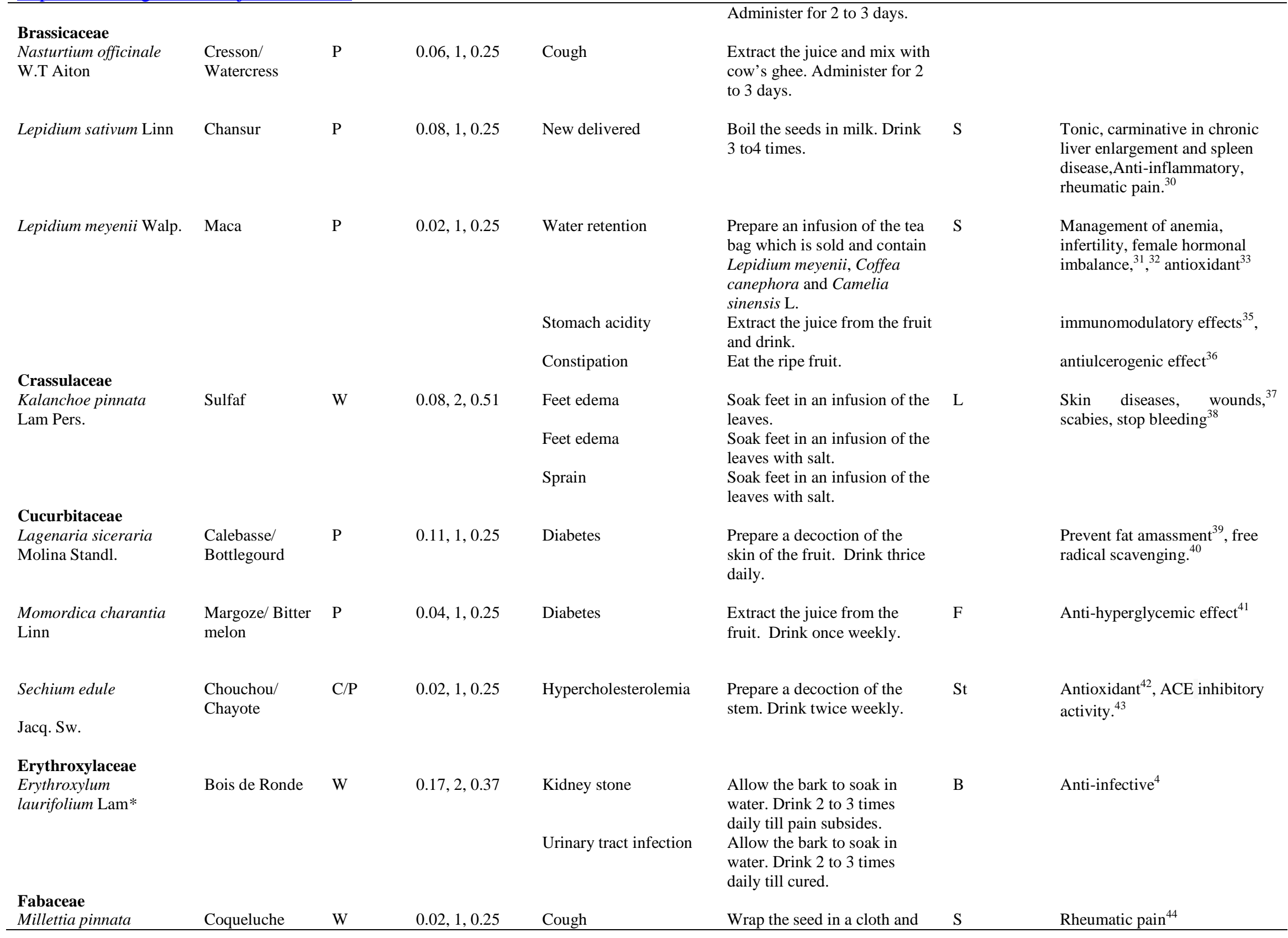


Mahomoodally Afr J Tradit Complement Altern Med. (2014) 11(6):1-32

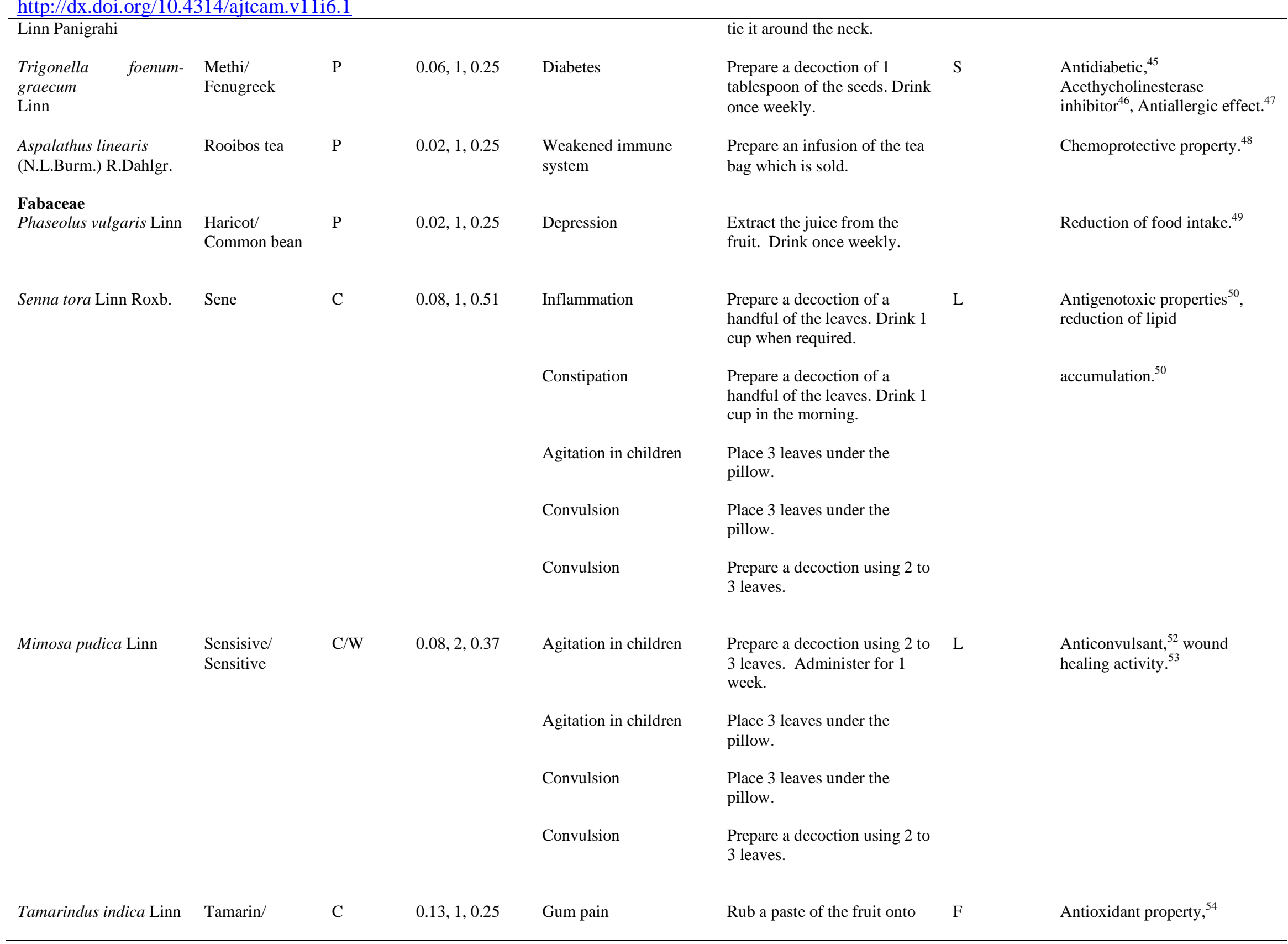


Mahomoodally Afr J Tradit Complement Altern Med. (2014) 11(6):1-32

\section{Gentianaceae}

Swertia chirata Lin

Chiraita

$0.36,3,0.62$

Fever

\section{Gentianaceae}

Swertia chirata Linn

Chiraita

$\mathrm{P}$

$0.36,3,0.62$

Fever

Fever

Loss of appetite

Lamiaceae

Plectranthus aromaticus Baume du Lour. Spreng
$0.45,2,0.37$ infection

\section{Lamiaceae}

Plectranthus aromaticus Baume du

Lour. Spreng

Perou

Mentha piperita Linn $\quad$ La menthe/ Peppermint

Prepare an infusion of the leaves. Drink 1 cup twice daily.

Prepare an infusion of the whole plant. Drink 1 cup daily for 2 to 3 days.

Prepare an infusion of the

stem. Drink 1 cup twice daily.

Prepare an infusion of the

stem. Drink 1 cup once

monthly.

Respiratory tract

Extract the juice from the leaves and sweeten with honey. Then heat with cow's ghee. Drink once at bedtime till cured.

Cough Prepare an infusion of

Plectranhus aromaticus

Plectranhus aromaticus

leaves. Drink once daily at night.

Respiratory tract

infection

Extract the juice from leaves

of Plectranhus aromaticus

and leaves of Piper betle $\mathrm{L}$.

Drink once at night till cured.

Cough

Heat the leaves then extract

the juice and sweeten with

honey.

Extract the juice form the leaves, mix with Citrus limonia, honey and butter. Drink once at night.

Prepare a decoction of the leaves. Drink 1 cup as required

Prepare an infusion of the

leaves together with leaves of Eupatorium triplinerve Vahl.
leaves together with leaves of Drink 1 cup as required
Hepatoprotective agent,

antifungal, antimalarial, antiinflammatory. ${ }^{56}$

Antioxidant ${ }^{57}$ antimicrobial, ${ }^{58}$ antihelmintic, ${ }^{59}$ antidiabetic. ${ }^{60}$ 
Mahomoodally Afr J Tradit Complement Altern Med. (2014) 11(6):1-32

\begin{tabular}{|c|c|c|c|c|c|c|c|}
\hline & & & & Flatulence & $\begin{array}{l}\text { Prepare a decoction of the } \\
\text { leaves. Drink } 1 \text { cup twice } \\
\text { daily. } \\
\text { Preapare a decoction of the } \\
\text { leaves, Pimpinella anisum } \\
\text { seeds and Illicium verum } \\
\text { fruits. Drink } 1 \text { cup as } \\
\text { required. } \\
\text { Prepare a decoction of the } \\
\text { leaves and the seeds of } \\
\text { Pimpinella anisum. Illicium } \\
\text { verum fruits, Ocimum } \\
\text { tenuiflorum leaves and } \\
\text { Zingiber officinale root. Drink } \\
\text { when required. }\end{array}$ & & \\
\hline \multirow[t]{2}{*}{ Thymus. vulgaris Linn } & Di tin/ Thyme & $\mathrm{C} / \mathrm{P}$ & $0.04,3,0.62$ & Influenza & $\begin{array}{l}\text { Prepare a decoction of the } \\
\text { stem and leaves. Drink } 1 \text { cup } \\
\text { for } 1 \text { week. }\end{array}$ & $\mathrm{L} \& \mathrm{St}$ & $\begin{array}{l}\text { Expectorant,antitussive, } \\
\text { anthelmintic, diuretic } \\
\text { properties }{ }^{63} \text { heals }\end{array}$ \\
\hline & Di tin/ Thyme & $\mathrm{C} / \mathrm{P}$ & $0.04,3,0.62$ & Flatulence & $\begin{array}{l}\text { Prepare a decoction of the } \\
\text { stem and leaves.Sweeten with } \\
\text { honey. Drink } 1 \text { cup daily till } \\
\text { cured. } \\
\text { Prepare an infusion of the } \\
\text { leaves. Drink } 2 \text { to } 3 \text { cups. }\end{array}$ & $\mathrm{L} \& \mathrm{St}$ & wound of mouth, evil tripe. ${ }^{64}$ \\
\hline $\begin{array}{l}\text { Ocimum } \\
\text { Linn }\end{array}$ & $\begin{array}{l}\text { Tulsi/ Holy } \\
\text { basil }\end{array}$ & $\mathrm{C}$ & $0.17,9,2$ & $\begin{array}{l}\text { Stomach acidity } \\
\text { Insomnia } \\
\text { Abdominal pain }\end{array}$ & $\begin{array}{l}\text { Prepare a decoction of a } \\
\text { handful of the leaves. Drink } 1 \\
\text { cup twice daily as required. } \\
\text { Prepare an infusion of the } \\
\text { leaves. Drink } 1 \text { cup for } 2 \text { to } 3 \\
\text { days. } \\
\text { Prepare a decoction of the } \\
\text { leaves. Drink } 1 \text { cup twice } \\
\text { daily. } \\
\text { Prepare a poultice of } \text { Ocimum } \\
\text { tenuiflorum leaves together } \\
\text { with Mentha piperita leaves. } \\
\text { Apply the paste on dark spots. } \\
\text { Prepare an infusion of the } \\
\text { leaves. Drink } 1 \text { cup once } \\
\text { weekly. } \\
\text { Prepare a decoction of the } \\
\text { leaves. Drink } 1 \text { cup daily. } \\
\text { Prepare a decoction of the } \\
\text { leaves. Drink } 1 \text { cup daily. } \\
\text { Prepare an infusion of the }\end{array}$ & $\mathrm{L}$ & $\begin{array}{l}\text { Antihyperglycaemic, }{ }^{65} \\
\text { antioxidant, }{ }^{66} \\
\text { antistress }{ }^{67} \text { antimicrobial, }{ }^{68} \\
\text { mosquito repellant activity, }{ }^{69} \\
\text { hypertension. }{ }^{70}\end{array}$ \\
\hline
\end{tabular}


Mahomoodally Afr J Tradit Complement Altern Med. (2014) 11(6):1-32

\section{Lamiaceae}

Ocimum tenuiflorum

Linn

Tulsi/ Holy

basil
$0.17,9,2$

Flatulence

Rosmarinus officinalis Romarin

Linn

\begin{tabular}{|c|c|}
\hline Salvia hispanica Linn & $\begin{array}{l}\text { Tourkmarya/ } \\
\text { Chia seeds }\end{array}$ \\
\hline Lauraceae & \\
\hline $\begin{array}{l}\text { Litsea glutinosa Lour. } \\
\text { C.B. Rob. }\end{array}$ & $\begin{array}{l}\text { Bois d'oiseau/ } \\
\text { Indian laurel }\end{array}$ \\
\hline
\end{tabular}

C.B. Rob.

Indian laurel

Cinnamomum verum

J. Presl

Canelle/

Cinnamon

$0.02,2,0.51$

Stress

Insomnia

$0.02,1,0.25$

W

$0.04,2,0.51$

$0.06,2,0.51$
Inflammation

Urinary tract infection

Inflammation

Hyperglycemia

Cough

\section{Liliaceae}

$\begin{array}{lllll}\text { Allium cepa } \text { Linn } & \begin{array}{l}\text { Zoiyuon } \\ \text { /Onion }\end{array} & \text { C/P } & 0.04,1,0.25 & \text { Earache } \\ \text { Allium cepa } \text { Linn } & \begin{array}{l}\text { Zoiyuon } \\ \text { blanc/White } \\ \text { onion }\end{array} & & 0.17,1,0.25 & \text { Dandruff } \\ \begin{array}{l}\text { Linaceae } \\ \begin{array}{l}\text { Linum usitatissimum } \\ \text { Linn }\end{array}\end{array} & \begin{array}{l}\text { Graine de } \\ \text { lin/Flaxseed }\end{array} & \text { P } & 0.19,2,0.37 & \text { Inflammation }\end{array}$

Inflammation leaves. Drink 1 cup once

daily.

Prepare a decoction of

Ocimum tenuiflorum leaves,

Pimpinella anisum seeds,

Illicium verum fruits, Mentha

piperita leaves and Zingiber

officinale root. Drink when

required.

Prepare an infusion of the leaves. Drink 1 cup daily. Inhale the aroma.

Place 1 teaspoonful of the seeds in water then drink.

Prepare an infusion of the leaves. Drink thrice daily.

Prepare an infusion of the leaves.

Prepare an infusion of the bark. Drink $1 / 2$ cup every 2

days.

Add the powdered form of the bark in milk. Drink 1 cup daily.

\section{Extract the juice from the} bulb. After warming, instill 1 drop in the ear.

Extract the juice from the bulb and apply with a piece of cotton onto the scalp.

Prepare a decoction of Linum usitatissimum, Hordeum vulgare seeds and Illicium verum fruits. Drink 2 to 3

$$
\text { times. }
$$

Prepare a decoction of Linum usitatissimum and Hordeum vulgare seeds. Drink 2 to 3
Antihyperglycaemic, ${ }^{65}$

antioxidant, ${ }^{66}$

antistress, ${ }^{67}$ antimicrobial, ${ }^{68}$

mosquito repellant activity, ${ }^{69}$

hypertension.

Antidepressant-like effect ${ }^{71}$

antidiabetic and

anti-inflammatory ${ }^{73}$, spasmolytic activity ${ }^{74}$

Antioxidant $^{75}$

Antibacterial $^{76}$, anti-

inflammatory and

hyperalgesic properties ${ }^{77}$.

Antioxidant activity and scavenging effects.

Dental infections, cancer, antihypertensive. $^{79}$

Antihyperglycaemic effect, inhibition of ROS level, ${ }^{80}$ phytosterols accumulation. ${ }^{81}$ 
Mahomoodally Afr J Tradit Complement Altern Med. (2014) 11(6):1-32

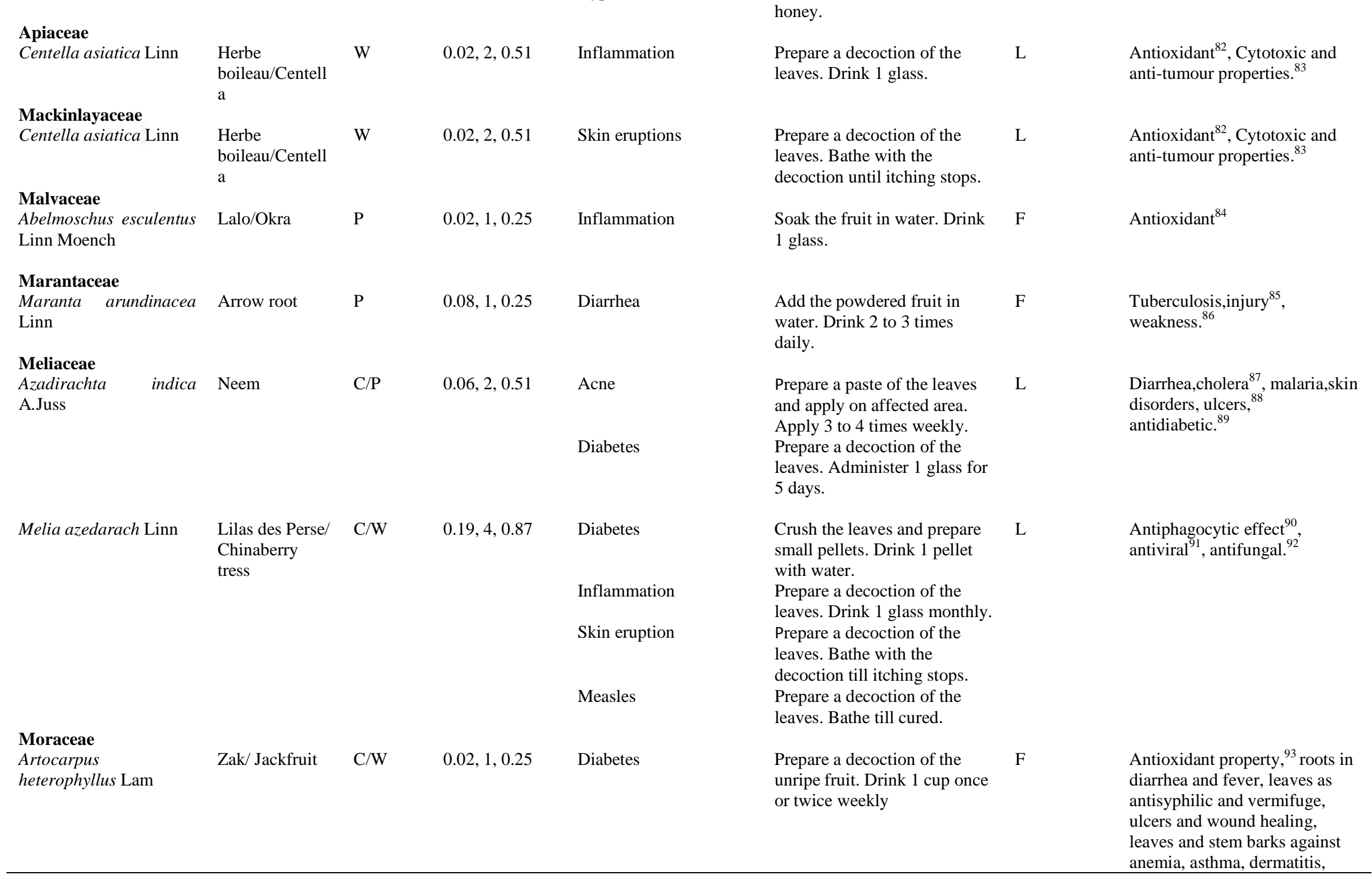

$\begin{array}{ll}\text { Hypercholesterolemia } & \begin{array}{l}\text { times. } \\ \text { Crush the seeds and drink } \\ \text { with water. }\end{array} \\ \text { Hypercholesterolemia } & \text { Crush the seeds and eat with }\end{array}$

$\begin{array}{ll}\text { Hypercholesterolemia } & \text { with water. } \\ \text { Crush the seeds and eat with }\end{array}$

Prepare a decoction of the leaves. Drink 1 glass.

Prepare a decoction of the leaves. Bathe with the

decoction until itching stops

Soak the fruit in water. Drink

Add the powdered fruit in water. Drink 2 to 3 time

Prepare a paste of the leaves and apply on affected area. Apply 3 to 4 times weekly. Prepare a decoction of the leaves. Administer 1 glass for

Crush the leaves and prepare small pellets. Drink 1 pellet leaves. Drink 1 glass monthly. epare a decoction of the leaves. Bathe with the Proction till itching stops.

Prepare a decoction of the unripe fruit. Drink 1 cup once anemia, asthma, dermatitis, 


\begin{tabular}{|c|c|c|c|c|c|c|c|}
\hline $\begin{array}{l}\text { Musaceae } \\
\text { Musa acuminate Colla }\end{array}$ & $\begin{array}{l}\text { Banane/ } \\
\text { Banana }\end{array}$ & $\mathrm{C}$ & $0.04,1,0.25$ & Fever & $\begin{array}{l}\text { Apply warm oil on leaf and } \\
\text { bind it to forehead. }\end{array}$ & $\mathrm{L}$ & Rheumatism, ${ }^{95}$ leshmaniasis. ${ }^{96}$ \\
\hline $\begin{array}{l}\text { Moringaceae } \\
\text { Moringa oleifera Lam }\end{array}$ & $\begin{array}{l}\text { Bred } \\
\text { mouroungue/ } \\
\text { Drumstick tree }\end{array}$ & $\mathrm{C}$ & $0.08,1,0.25$ & Skin eruption & $\begin{array}{l}\text { Prepare a decoction of the leaf } \\
\text { and stem. Drink } 2 \text { to } 3 \text { times } \\
\text { daily. }\end{array}$ & L \& St & \\
\hline $\begin{array}{l}\text { Myrtaceae } \\
\text { Eucalyptus globulus } \\
\text { Labill. }\end{array}$ & $\begin{array}{l}\text { Eucalyptis / } \\
\text { Eucalyptus }\end{array}$ & $\mathrm{W}$ & $0.06,1,0.25$ & Asthma & $\begin{array}{l}\text { Prepare a hot infusion of } \\
\text { leaves and inhale vapour. }\end{array}$ & $\mathrm{L}$ & $\begin{array}{l}\text { Expectorant, cough }{ }^{7}, \\
\text { antibacterial activity. }\end{array}$ \\
\hline Psidium guajava Linn & Goyave/ Guava & $\mathrm{C} / \mathrm{W}$ & $0.11,1,0.25$ & Diarrhea & $\begin{array}{l}\text { Prepare a decoction of the } \\
\text { leaves and drink } 1 \text { cup once } \\
\text { daily. }\end{array}$ & $\mathrm{L}$ & $\begin{array}{l}\text { Dysentery }{ }^{100}, \text { cough, pre-hepatic } \\
\text { jaundice, diarrhea }{ }^{101}\end{array}$ \\
\hline \multirow[t]{2}{*}{$\begin{array}{l}\text { Syzygium aromaticum } \\
\text { Linn }\end{array}$} & Girrofle/ Clove & $\mathrm{p}$ & $0.09,3,0.62$ & Cough & $\begin{array}{l}\text { Boil the dried flower buds in } \\
\text { milk. Drink once at night until } \\
\text { cough subsides. }\end{array}$ & $\mathrm{Fl}$ & $\begin{array}{l}\text { Antimicrobial, analgesic, anti- } \\
\text { inflammatory and healing } \\
\text { agent. }^{102}\end{array}$ \\
\hline & & & & Toothache & $\begin{array}{l}\text { Mix the powdered dried } \\
\text { flower buds of Syzygium } \\
\text { aromaticum with powdred } \\
\text { Zingiber officinale Roscoe. } \\
\text { Administer with honey once } \\
\text { daily. } \\
\text { Apply oil of clove which is } \\
\text { sold. }\end{array}$ & $\mathrm{Fl}$ & $\begin{array}{l}\text { Antimicrobial, analgesic, anti- } \\
\text { inflammatory and healing } \\
\text { agent. }{ }^{102}\end{array}$ \\
\hline \multirow[t]{2}{*}{$\begin{array}{l}\text { Syzygium cumini Linn } \\
\text { Skeels }\end{array}$} & $\begin{array}{l}\text { Jamblon/ } \\
\text { Jambul }\end{array}$ & $\mathrm{C} / \mathrm{W}$ & $0.08,1,0.25$ & Diabetes & $\begin{array}{l}\text { Prepare a decoction of the } \\
\text { leaves. Drink } 1 \text { cup once per } \\
\text { week. }\end{array}$ & $\mathrm{L}$ & Diabetes $^{103}$ \\
\hline & & & & Diabetes & $\begin{array}{l}\text { Prepare an infusion of the } \\
\text { seeds. Drink } 1 \text { cup twice per } \\
\text { week. }\end{array}$ & S & \\
\hline $\begin{array}{l}\text { Oleaceae } \\
\text { Olea europaea Linn }\end{array}$ & Zolive/Olive & $\mathrm{C} / \mathrm{W}$ & $0.06,1,0.25$ & High blood pressure & $\begin{array}{l}\text { Prepare an infusion of the } \\
\text { leaves. Drink twice or thrice } \\
\text { per day for } 1 \text { week. }\end{array}$ & $\mathrm{L}$ & $\begin{array}{l}\text { Supression of L- type calcium } \\
\text { channel }^{104} \text {, antioxidant } \\
\text { activity. }{ }^{105}\end{array}$ \\
\hline \multirow[t]{3}{*}{$\begin{array}{l}\text { Piperaceae } \\
\text { Piper betel Linn }\end{array}$} & Betel & $\mathrm{C}$ & $0.28,4,0.87$ & Cough & $\begin{array}{l}\text { Prepare a decoction of the } \\
\text { leaves. Drink } 1 \text { cup daily at } \\
\text { night. }\end{array}$ & $\mathrm{L}$ & $\begin{array}{l}\text { Leprosy, bronchitis, asthma } \\
\text { antidiabetic activity }\end{array}$ \\
\hline & & & & Cough & $\begin{array}{l}\text { Extract the juice and sweeten } \\
\text { with honey. Administer once } \\
\text { at night for } 3 \text { days. }\end{array}$ & & \\
\hline & & & & Cough & $\begin{array}{l}\text { Prepare an infusion of the } \\
\text { leaves together with leaves of }\end{array}$ & & \\
\hline
\end{tabular}




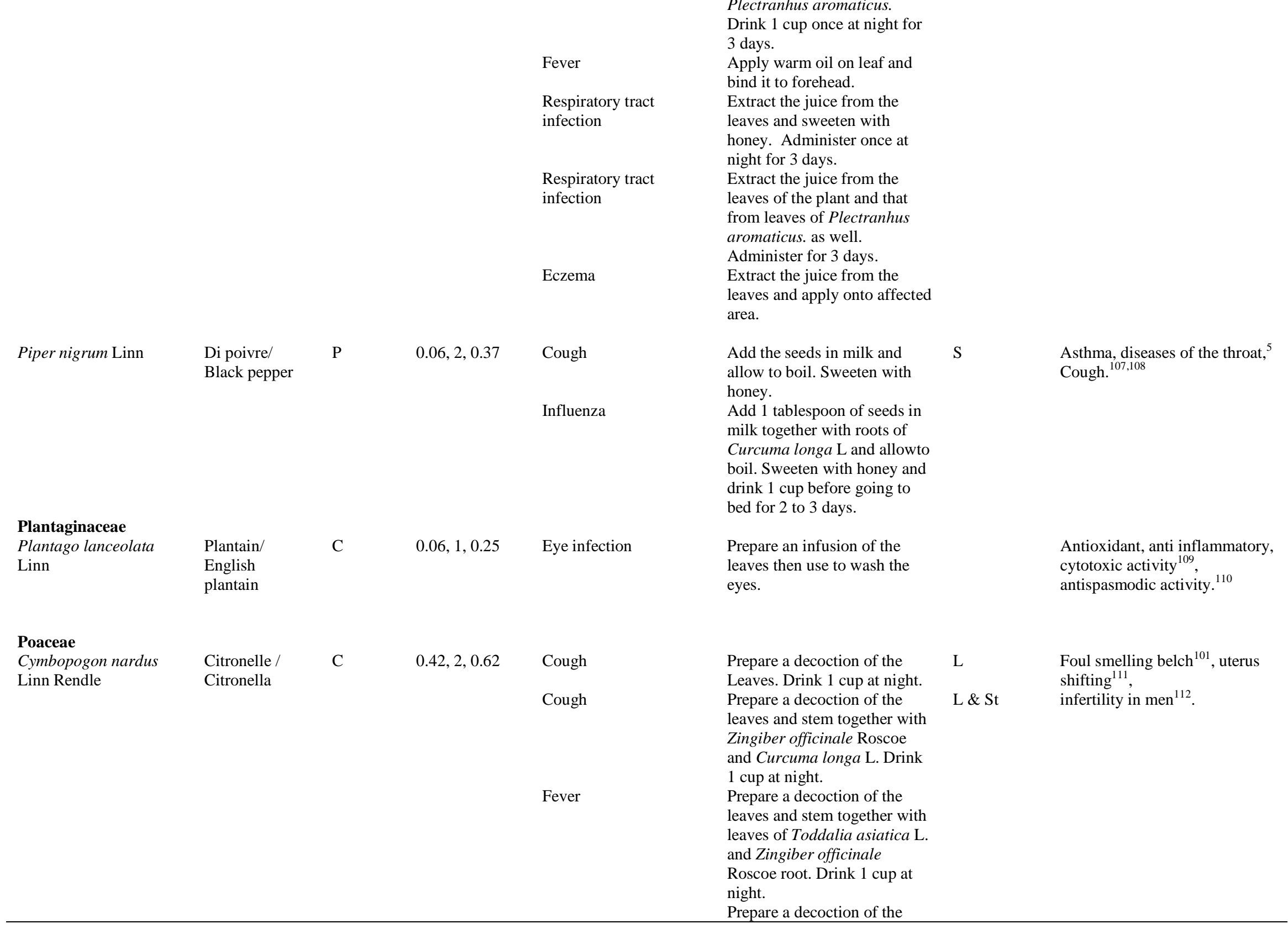




\begin{tabular}{|c|c|c|c|c|c|c|c|}
\hline $\begin{array}{l}\text { Cymbopogon citratus } \\
\text { DC. Stapf }\end{array}$ & Lemongrass & $\mathrm{C} / \mathrm{W}$ & $0.02,1,0.25$ & Influenza & $\begin{array}{l}\text { Prepare an infusion of the } \\
\text { stem and leaves. Drink } 1 \text { cup } \\
\text { daily till cured. }\end{array}$ & $\mathrm{L} \& \mathrm{St}$ & $\begin{array}{l}\text { Cardiopathy, hypertension, } \\
\text { nervousness, }{ }^{113} \text { antimicrobial } \\
\text { activity }{ }^{14} \text {. }\end{array}$ \\
\hline Bambusa bambos Linn & Bamboo & W & $0.04,1,0.25$ & Pimple onto eyelid & $\begin{array}{l}\text { Rub the leaves onto the } \\
\text { pimple. }\end{array}$ & $\mathrm{L}$ & $\begin{array}{l}\text { As emmenagogue } \\
\text { antithrombotic }\end{array}$ \\
\hline \multicolumn{8}{|l|}{ Poaceae } \\
\hline \multirow[t]{2}{*}{ Triticum aestivum Linn } & \multirow[t]{2}{*}{$\begin{array}{l}\text { Sirdar/ } \\
\text { Wheatgrass }\end{array}$} & \multirow[t]{2}{*}{ W } & \multirow[t]{2}{*}{$0.04,2,0.51$} & Cancer & $\begin{array}{l}\text { Extract the juice from the } \\
\text { leaves. Drink } 1 \text { cup daily. }\end{array}$ & \multirow[t]{2}{*}{$\mathrm{L}$} & \multirow{2}{*}{$\begin{array}{l}\text { Anti-cancer, anti-ulcer activity, } \\
\text { antioxidant } \\
\text { activity, anti-arthritic activity, } \\
\text { blood building activity in } \\
\text { Thalassemia major. }{ }^{117}\end{array}$} \\
\hline & & & & $\begin{array}{l}\text { Weakened immune } \\
\text { system }\end{array}$ & $\begin{array}{l}\text { Extract the juice from the } \\
\text { leaves. Drink } 1 \text { cup per } \\
\text { month. }\end{array}$ & & \\
\hline $\begin{array}{l}\text { Triticum monococcum } \\
\text { Linn }\end{array}$ & La farine/ Flour & $\mathrm{P}$ & $0.08,1,0.25$ & Diarrhea & $\begin{array}{l}\text { Add flour in soft drink. Drink } \\
2 \text { or } 3 \text { times. }\end{array}$ & $S$ & Malaria $^{118}$ \\
\hline \multicolumn{8}{|l|}{ Punicaceae } \\
\hline \multirow[t]{2}{*}{ Punica granatum Linn } & \multirow[t]{2}{*}{$\begin{array}{l}\text { grenade/ } \\
\text { Pomegrenate }\end{array}$} & \multirow[t]{2}{*}{$\mathrm{C}$} & \multirow[t]{2}{*}{$0.15,2,0.37$} & Diarrhea & $\begin{array}{l}\text { Prepare a decoction of the } \\
\text { mesocarp of the unripe fruit. } \\
\text { Drink } 1 \text { cup twice daily. }\end{array}$ & $\mathrm{F}$ & \multirow[t]{2}{*}{$\begin{array}{l}\text { Diarrhea, }{ }^{119} \text { bronchitis, sore } \\
\text { throat, chest troubles }\end{array}$} \\
\hline & & & & Bleeding of gums & $\begin{array}{l}\text { Prepare a decoction of the } \\
\text { mesocarp of the unripe fruit } \\
\text { and once cooled use to wash } \\
\text { the gums. }\end{array}$ & $\mathrm{F}$ & \\
\hline \multicolumn{8}{|l|}{ Ranunculaceae } \\
\hline Nigella sativa & Blackseed & $\mathrm{P}$ & $0.02,1,0.25$ & $\begin{array}{l}\text { Weakened immune } \\
\text { system }\end{array}$ & $\begin{array}{l}\text { Crush the seeds to powder } \\
\text { form and administer with }\end{array}$ & $S$ & Lung complaints, cough, fever. ${ }^{7}$ \\
\hline Linn & & & & & honey. & & \\
\hline \multicolumn{8}{|l|}{ Rosaseae } \\
\hline $\begin{array}{l}\text { Prunus persica } \\
\text { Linn Stokes }\end{array}$ & Peche/Peach & $\mathrm{C}$ & $0.02,1,0.25$ & Diarrhea & Eat the unripe fruit. & $\mathrm{F}$ & $\begin{array}{l}\text { Remove maggots from wounds, } \\
\text { demulcent, lubricant, }{ }^{120} \text { cough, } \\
\text { bronchitis, expectorant }{ }^{5} \text {. }\end{array}$ \\
\hline \multirow[t]{2}{*}{$\begin{array}{l}\text { Rubiaceae } \\
\text { Paederia tomentosa } \\
\text { Blume }\end{array}$} & \multirow[t]{2}{*}{ La liane lingue } & \multirow[t]{2}{*}{ W } & \multirow[t]{2}{*}{$0.04,2,0.37$} & Stomach acidity & $\begin{array}{l}\text { Prepare an infusion of the } \\
\text { leaves and drink } 1 \text { glass as } \\
\text { required. }\end{array}$ & \multirow[t]{2}{*}{$\mathrm{L}$} & \multirow[t]{2}{*}{ Eczema, indigestion,ulcers. ${ }^{121}$} \\
\hline & & & & Abdominal pain & Prepare an infusion of the & & \\
\hline
\end{tabular}

nd stem together wi

Zingiber officinale Roscoe.

Drink 1 cup at night.

Prepare a decoction of the

leaves and stem together with

Zingiber officinale Roscoe.

Sweeten with honey. Drink

cup at night.

stem and leaves. Drink 1 cup

aily till cured.

pimple.

leaves. Drink 1 cup daily.

Extract the juice from the

leaves. Drink 1 cup per

Add flour in soft drink. Drink

2 or 3 times.

Drink 1 cup twice daily.

form and administer with

Peaves and drink 1 glass as

Prepare an infusion of the 
Mahomoodally Afr J Tradit Complement Altern Med. (2014) 11(6):1-32

\begin{tabular}{|c|c|c|c|c|c|c|c|}
\hline \multirow[t]{3}{*}{ Morinda citrifolia Linn } & \multirow[t]{3}{*}{$\begin{array}{l}\text { Feuille tortue/ } \\
\text { Noni }\end{array}$} & \multirow[t]{3}{*}{$\mathrm{W}$} & \multirow[t]{3}{*}{$0.2,2,0.51$} & Diabetes & Eat the fruit in the morning. & $\mathrm{F}$ & \multirow[t]{3}{*}{$\begin{array}{l}\text { Antioxidant activity }{ }^{122} \\
\text { treatment of gastro esophageal } \\
\text { disease. }^{123}\end{array}$} \\
\hline & & & & Diabetes & $\begin{array}{l}\text { Extract the juice from the } \\
\text { fruit. Drink once daily. }\end{array}$ & & \\
\hline & & & & Pain & $\begin{array}{l}\text { Heat the leaf and spread oil } \\
\text { onto it, then bind to body part } \\
\text { where there is pain. }\end{array}$ & $\mathrm{L}$ & \\
\hline \multicolumn{8}{|l|}{ Rutaceae } \\
\hline Toddalia asiatica Lam* & La patte poule & W & $0.04,2,0.51$ & Fever & $\begin{array}{l}\text { Prepare a decoction of the } \\
\text { leaves together with } \\
\text { Cymbopogon nardus L. and } \\
\text { Zingiber officinale Roscoe } \\
\text { root. Drink } 1 \text { cup at night. }\end{array}$ & $\mathrm{L}$ & $\begin{array}{l}\text { Malaria, cough, influenza,lung } \\
\text { disease, rheumatism, nasal and } \\
\text { bronchial pain,stomach ache, } \\
\text { snake bites. }{ }^{24}\end{array}$ \\
\hline & & & & Trauma & $\begin{array}{l}\text { Prepare a poultice of Toddalia } \\
\text { asiatica L.leaves together } \\
\text { with Curcuma longa L and } \\
\text { apply on wound }\end{array}$ & & \\
\hline $\begin{array}{l}\text { Murraya koenigii } \\
\text { Linn Sprengel }\end{array}$ & $\begin{array}{l}\text { Carripoule/ } \\
\text { Curry leaf }\end{array}$ & $\mathrm{C} / \mathrm{P}$ & $0.13,1,0.25$ & High blood pressure & $\begin{array}{l}\text { Prepare an infusion of the } \\
\text { leaves.Drink } 1 \text { cup once per } \\
\text { week. }\end{array}$ & $\mathrm{L}$ & $\begin{array}{l}\text { Nephroprotective agent in } \\
\text { kidney infirmities among } \\
\text { diabetic }{ }^{125} \text {,anti-obesity and } \\
\text { hypoglycemic effect. }{ }^{126}\end{array}$ \\
\hline \multicolumn{8}{|l|}{ Rutaceae } \\
\hline \multirow[t]{5}{*}{ Citrus limonia Osbeck } & Limon/ Lemon & $\mathrm{P}$ & $0.17,3,0.62$ & Cough & $\begin{array}{l}\text { Add a slice of Citrus limonia, } \\
\text { Curcuma longa L.and cow's } \\
\text { ghee to milk and allow to } \\
\text { boil. Sweeten with sugar and } \\
\text { honey. Drink 1cup a night till } \\
\text { cured }\end{array}$ & $\mathrm{F}$ & $\begin{array}{l}\text { Antioxidant, anti inflammatory, } \\
\text { anti- carcinogenic activities } \\
\text { carminative and antimicrobial } \\
\text { effect. }{ }^{127}\end{array}$ \\
\hline & & & & High blood pressure & $\begin{array}{l}\text { Prepare the fruit together with } \\
\text { Allium sativum L. in the form } \\
\text { of pickle. Eat daily. }\end{array}$ & & \\
\hline & & & & Influenza & $\begin{array}{l}\text { Extract the juice from the fruit } \\
\text { and add few drops in } \\
\text { Camellia sinensis } L \text {. Drink } 2 \\
\text { or } 3 \text { times daily till cured. }\end{array}$ & & \\
\hline & & & & Cough & $\begin{array}{l}\text { Extract the juice from the fruit } \\
\text { and add few drops in }\end{array}$ & & \\
\hline & & & & & $\begin{array}{l}\text { Camellia sinensis } L \text {. Drink } 2 \\
\text { or } 3 \text { times daily till cured }\end{array}$ & & \\
\hline $\begin{array}{l}\text { Citrus aurantiifolia } \\
\text { Christm. Swingle }\end{array}$ & Orange & $\mathrm{P}$ & $0.02,1,0.25$ & Cough & $\begin{array}{l}\text { Extract the juice from the fruit } \\
\text { of Citrus aurantiifolia and } \\
\text { additionally from the stem of }\end{array}$ & $\mathrm{F}$ & ${ }_{30}$ Antidiabetic, ${ }^{128}$ antimalarial. ${ }^{129,1}$ \\
\hline
\end{tabular}


Mahomoodally Afr J Tradit Complement Altern Med. (2014) 11(6):1-32

Sapindaceae

Cardiospermum

halicacabum Linn

Feuille pok pok

/ Ballon plant

Schisandraceae

Illicium verum

Hook.f

Anis etoile/

Star anise

Flatulence

Flatulence

Flatulence

\section{Theaceae}

Camellia sinensis

Di the/ Tea

$0.04,5,1.13$

Influenza

Linn Kuntze
Nasturtium officinale. Then

sweeten with honey.

Administer for 2 to 3 days.

Prepare a decoction of the

leaves and bathe with it.Use

the leaves to rub onto affected

area.

Prepare a decoction of

Illicium verum fruits,

Hordeum vulgare seeds an

Linum usitatissium seeds,

Drink 2 to 3 times.

Prepare a decoction of

Pimpinella anisum seeds,

Eupatorium triplinerve Vahl.

leaves and Illicium verum

fruits. Drink when required.

Prepare a decoction of

Illicium verum fruits and

Pimpinella anisum seeds.

Drink when required.

Prepare a decoction of

Illicium verum fruits,

Pimpinella anisum seeds,

Mentha piperita leaves,

Ocimum tenuiflorum leaves

and Zingiber officinale

root.Drink when required.

Extract the juice from the fruit L

of Citrus limonia and add few

drops in Camellia sinensis $L$

infusion. Drink 2 or 3 times

daily till cured.

Eye infection

Prepare a decoction of the tea bag and when decoction cools use to wash eye twice daily. Extract the juice from the fruit of Citrus limonia and add few

drops in Camellia sinensis $L$

infusion. Drink 2 or 3 times
Cough
Rheumatism,nervous

diseases,demulcent, ${ }^{131}$

treatment of abscesses and

septic wounds. ${ }^{132}$

Cold, pain, ${ }^{133}$

antiinflammatory. ${ }^{134}$
Potent diuretic activity, urinary inconsistency, common

cold,suppress anxiety, improve sexual function, ${ }^{135}$ anticancer activity, lipid lowering activity, anticataract activity,

hepatoprotective and

antioxidant. 
Mahomoodally Afr J Tradit Complement Altern Med. (2014) 11(6):1-32

\section{Thymelaeaceae}

Wikstroemia viridiflora Herbe

Meissn

tourterelle

\section{Xanthorrhoeaceae}

Aloe vera
Aloe vera Ling

Indigestion

Water retention

$0.23,5$

Acne

Pain

Diabetes

Constipation

Stomach acidity

Lomatophyllum

purpureum Lam

Curcuma longa Linn

\section{Mazambron}

marron

Saffran vert/

Turmeric
Prepare an infusion of the tea

bag. Drink 1 cup after a heavy meal.

Prepare an infusion of the tea bag which is sold and contain Lepidium meyenii together with Coffea canephora and Camellia sinensis L.

Prepare a decoction of the leaves together with seeds of Lens culinaris. Administer twice.

Remove the skin from the leaves and apply the gel onto the affected area.

Remove the skin from the leaves and apply the gel onto the affected area.

Remove the skin and eat the gel daily.

Remove the skin and eat the gel.

Remove the skin and eat the gel 2 to 3 times daily.

Heat the leaf then extract juice L and instill 1 drop in the ear

Crush the roots of Curcuma longa L.then boil in milk together with Piper nigrum and 1 tablespoon of honey. Drink hot before going to bed for 2 to 3 days.

Crush the roots and boil with milk. Drink once daily at night for 1 week.

Mix the juice obtained from

crushed Curcuma longa

L.with milk. Drink once daily

at night
Potent diuretic activity, urinary inconsistency, common cold,suppress anxiety, improve sexual function, ${ }^{135}$ anticancer activity, lipid lowering activity, anticataract activity,

hepatoprotective and

antioxidant.

Anemia. ${ }^{137}$

Antioxidant activity, ${ }^{138}$ Antiinflammatory activity, ${ }^{139}$ hypoglycemic and

hypolipidemic activity, ${ }^{140}$

wound healing activity, ${ }^{14}$

gastroprotective activity, ${ }^{142}$

immunomodulatory activity, ${ }^{143}$ antifungal. ${ }^{144}$
Resolves phlegm, relieves

depression, ${ }^{145}$ stomac

tonic, blood, skin diseases,

wound healing. ${ }^{146}$ 
Mahomoodally Afr J Tradit Complement Altern Med. (2014) 11(6):1-32

\section{Zingiberaceae}

Curcum

\section{Saffran vert/ \\ Turmeric}

$\mathrm{C} / \mathrm{P}$

$0.36,5,0.98$

\section{Cough}

Trauma

Trauma

cne

Fever

Zingiber

officinale

Gingembre/

Ginger
Grate the roots of Curcuma

longa roots of Zingiber

officinale. Then, boil in milk.

Drink once daily at night.

Crush the roots and boil with

milk. Drink 2 to 3 times.

Prepare a poultice of

Curcuma longa $\mathrm{L}$. together

with the leaves of Toddalia

asiatica $\mathrm{L}$. and apply on

wound.

Prepare a poultice of the

roots, mix with oil and bind onto affected area

Cruhs the roots and mix with besan powder and water.

Apply on face 2 to 3 times weekly.

Prepare a decoction of the

root together with

Cymbopogon nardus L. and

Toddalia asiatica $\mathrm{L}$.

leaves. Drink 1 cup at night.

Prepare an infusion of the root. Drink $1 / 2$ cup for 1 week.

Prepare an infusion of the crushed root. Drink at 1 cup. Prepare a decoction of the crushed root. Drink at 1 cup Prepare an infusion of the root with Camellia sinensis L. Drink 1 cup at night till cured.

Mix the powdered dried

flower buds of Syzygium

aromaticum with pow

aromaticum with powdered

Zingiber officinale Roscoe

root.Administer with honey once daily.

Cough
Prepare a decoction of the

stem and leaves of

Cymbopogon nardus $L$. and

Zingiber officinale Roscoe.
Resolves phlegm, relieves

depression, ${ }^{145}$ stomach

tonic, blood, skin diseases,

wound healing. ${ }^{146}$

Cough,stomach pains caused by

heavy colds, carminative,

digestive, improving

circulation, aphrodisiac. ${ }^{147}$ 


$\begin{array}{ll} & \text { Sweeten with honey. Drink 1 } \\ \text { Cough } & \text { Prepare a decoction of the } \\ & \text { stem and the leaves of } \\ & \text { Cymbopogon nardus } \\ & \text { L.together with Zingiber } \\ & \text { officinale } \text { Roscoe root and } \\ & \text { Curcuma longa } \text { L.Drink 1 cup } \\ & \text { at night. } \\ \text { Hiccup } & \text { Prepare a decoction of the } \\ & \text { root. Drink 1 cup. }\end{array}$

Source: C, Cultivated; W, Wild; P, Purchased; RFC: Relative frequency of citation, VU: Variety of use, RI: Relative importance; Plant part used: L, Leaf; R, Root; S, Seed; F, Fruit; Fl, Flower, St, Stem ; Bu, Bulb; B; Bark; W, Whole; VN/CEN: Vernacular name/ common English name. * indicates plants that are endemic to Mauritius

1: Harris et al. 2001; 2: Bergman et al. 2001; 3: Ceuterick et al. 2008; 4: Rangasamy et al. 2007; 5: Kirtikar et al. 1935; 6: Antoun et al. 2001; 7: Newton et al. 2002; 8:Kaur et al. 2009; $9:$ Mahendra et al. 2011; 10: Tavare et al. 2008; 11 : Moazedi et al. 2007; 12 : Al-Howiriny et al. 2003; 13: : Ozsoy-Sacan et al. 2006; 14: Kreydiyyeh et al. 2001; 15: Wong et al. 2006;16:Tirapelli et al. 2007; 17:Gulcin et al. 2003; 18: Singhal et al. 2012; 19: Al-Adhroey et al. 2011;20: Jonville et al. 2011; 21: Loggia et al. 1982; $22:$ Murti et al. 2013; 23: Sun et al. 2012; 24: Harel et al. 2011; 25: 17:Gulcin et al. 2003; 18: Singhal et al. 2012; 19: Al-Adhroey et al. 2011; 20: Jonville et al. 2011; $21:$ Loggia et al. 1982; $22:$ Murti et al. 2013; 23: Sun et al. 2012; 24: Harel et al. 2011; 25:
Nweze et al. 2009; 26: Kaisoon et al. 2011; 27: Gouveia. et al. 2012; 28: Tenore et al. 2012; 29: Yazdanparast et al. 2008; 30: Bigoniya et al. 2011; 31: Hudson. 2008; 32:Lentz et al. 2006; 33: Sandoval et al. 2002; 34: Amazu et al. 2010; 35: Otsuki et al. 2010; 36: Ologundudu et al.2008; 37: Muzitano et al. 2011; 38: Namsa et al. 2009; 39: Nadeem et al. 2012; 40 : Mayakrishnan et al. 2013; 41: Virdi et al. 2003; 42: Ordoñez et al. 2006; 43: Hansen et al. 1996; 44: Rajakumar et al. 2009; 45: Hamza et al. 2012; 46: Satheeshkumar et al. $2010 ; 47$ :Bae et al. $2012 ; 48$ : Marnewick et al. $2008 ; 49$ : Loi et al. $2013 ; 50: W u$ et al. $2004 ; 51:$ Tzeng et al. 2013; $52:$ Bum et al. 2004; 53: Kokane et al. $2009 ; 54:$ Komutarin et al. $2004 ; 55:$ Maiti et al. $2004 ; 56:$ Chen et al. $2011 ; 57$

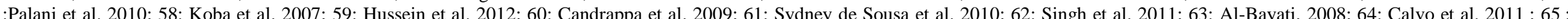
Arenal et al. 2012; 66: Juntachote et al. 2005; 67: Saxena et al. 2012; 68: Sermakkani et al. 2011; 69: Chokechaijaroenporn et al. 1994; 70 : Paulino de Albuquerque et al. 2007; 71: Machado et al. $2012 ; 72$ : Bakirel et al. $2008 ; 73$ : Beninca et al. $2011 ; 74:$ Martinez et al. $2011 ; 75$ : Caudillo et al. $2008 ; 76$; Mandal et al. 2000 ;77 : Simao da Silva et al. $2012 ; 78$ : Mathew et al. $2006 ; 79$; Aburjai et al. 2007; 80 : Ghule et al. 2012;81: Herchi et al. 2009; 82: Hamid et al. 2002;83: Babu et al. 1995; $84:$ Adelakun et al. 2011; 85: Coelho-Ferreira. 2009; 86: Zheng et al. 2009; 87: Thakurta et al. 2007; 88: Vinod et al. 2011; 89: Courreges et al. 1994;90: Dallaqua et al. 2012; 91: Wachsman et al .1987; 92: Carpinella et al. 1999; 93: Jagtap et al. 2011; 94: Jagtap et al. 2010; 95: Marc et al. 2008; 96: Gachet et al. 2010; 97 : Moyo et al. 2012; 98: Hamza, 2010; 99: Bachin and Benali, 2012 ; 100 : Au et al. 2008; 101: Ssegawa and Kasenene, 2007; 102 : Panahi et al. 2012 ;

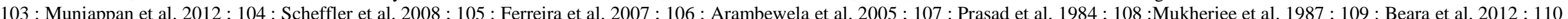
Fleer et al. $2007 ; 111$ : Polio et al. 2008; 112: Namukobe et al. $2011 ; 113:$ Hajdu and Hohmann, $2012 ; 114:$ Bassole et al. $2011 ; 115:$ Kumar et al. 2012 a; 116 : Pandikumar et al. $2011 ; 117:$ Singh et al. 2012a; 118 : Adams et al. 2011; 119: Boulogne et al. 2011; 120: Abbasi et al. 2010; $121:$ Sussman. 1980; 122: Liu et al. 2007; 123: Mahattanadul et al. 2011; 124: Orwa et al. 2008;125: Yanzuko et al. $2011 ; 126$ : Tembhurne et al. $2012 ; 127$ : Murali et al. 2012; 128 : Gbolade. 2009; 129 : Ajibesin et al. 2008 ; 130 : Kaou et al. 2008 ; 131 : Huang et al. 2011; 132: Maregesi et al. 2008; 133 : Wang et al. 2011; 134 : Sung et al. 2012; 135: Ratnasooriya et al. 2008; 136: Kumar et al. 2012b ; 137 : Chintamunnee and Mahoomoodally 2010; 138: El-Shemy et al. 2010; 139: Langmead et al. 2004; 140: Kim et al.2009; 141: Davis et al. 1989; 142: Snezana, 2007; 143: Yusuf et al. 2004; 144: Jasso de Rodriguez et al. 2005; 145: Xia et al. 2007; 146: Habiboallah et al. 2008; 147: Jaric et al. 2011 
Mahomoodally Afr J Tradit Complement Altern Med. (2014) 11(6):1-32

http://dx.doi.org/10.4314/ajtcam.v11i6.1

Table 4 : Fidelity level and index of agreement on remedies of plants with a minimum of 10 citations for an illness category.

\begin{tabular}{|c|c|c|c|}
\hline Disease category & Species & FL & IAR \\
\hline Disease of the ear and mastoid process & Lomatophyllum purpureum & $\begin{array}{l}1.00 \\
1.00\end{array}$ & $\begin{array}{l}1.00 \\
0.98\end{array}$ \\
\hline Disease of the respiratory system & $\begin{array}{l}\text { Curcuma longa } \\
\text { Cymbopogon nardus } \\
\text { Piper betle } \\
\text { Plectranhus aromaticus } \\
\text { Nasturtium officinale } \\
\text { Zingiber officinale Roscoe }\end{array}$ & $\begin{array}{l}0.72 \\
0.36 \\
1.00 \\
1.00 \\
0.90 \\
1.00\end{array}$ & $\begin{array}{l}1.00 \\
0.98 \\
1.00 \\
1.00 \\
0.98 \\
1.00\end{array}$ \\
\hline Disease of the eye and adnea & $\begin{array}{l}\text { Plantago lanceolata } \\
\text { Mangifera indica }\end{array}$ & $\begin{array}{l}1.00 \\
0.80\end{array}$ & $\begin{array}{l}1.00 \\
1.00\end{array}$ \\
\hline Disease of the circulatory system & $\begin{array}{l}\text { Linum usitatissimum } \\
\text { Tagetes lucida } \\
\text { Wikstroemia viridiflora Meissn } \\
\text { Daucus carota } \\
\text { Melia azedarach } \\
\text { Petroselinum crispum } \\
\text { Olea europaea }\end{array}$ & $\begin{array}{l}0.80 \\
1.00 \\
1.00 \\
0.50 \\
0.83 \\
1.00\end{array}$ & $\begin{array}{l}0.95 \\
1.00 \\
1.00 \\
0.98 \\
1.00 \\
1.00\end{array}$ \\
\hline & Litsea glutinosa & 1.00 & 0.91 \\
\hline Injury and poisons of external causes & $\begin{array}{l}\text { Moringa oleifera } \\
\text { Erythroxylum laurifolium }\end{array}$ & $\begin{array}{l}1.00 \\
1.00\end{array}$ & $\begin{array}{l}1.00 \\
1.00\end{array}$ \\
\hline Disease of the genitourinary system & Chamomilla recutita & 0.56 & 0.96 \\
\hline Undefined pains or illnes & $\begin{array}{l}\text { Piper betle } \\
\text { Swertia chirata } \\
\text { Cynara cardunculus var. scolymus } \\
\text { Kalanchoe pinnata } \\
\text { Morinda citrifolia }\end{array}$ & $\begin{array}{l}0.50 \\
0.79 \\
0.75 \\
1.00 \\
0.50\end{array}$ & $\begin{array}{l}0.98 \\
0.99 \\
0.99 \\
0.96 \\
0.98\end{array}$ \\
\hline Disease during the postpartum period & Lepidium sativum & 1.00 & 1.00 \\
\hline Infectious and parasitic diseases & Allium sativum & 0.60 & 0.92 \\
\hline Disease of the skin and subcutaneous tissue & $\begin{array}{l}\text { Cardiospermum halicacabum } \\
\text { Nerium oleander }\end{array}$ & $\begin{array}{l}1.00 \\
1.00\end{array}$ & $\begin{array}{l}1.00 \\
1.00\end{array}$ \\
\hline Disease of the digestive system & $\begin{array}{l}\text { Mentha piperita } \\
\text { Eupatorium triplinerve } \\
\text { Pimpinella anisum } \\
\text { Psidium guajava } \\
\text { Illicium verum } \\
\text { Ocimum tenuiflorum } \\
\text { Punica granatum } \\
\text { Aloe vera } \\
\text { Brassica rapa } \\
\text { Tamarindus indica } \\
\text { Carica papaya } \\
\text { Ageratum conyzoides } \\
\text { Triticum monococcum }\end{array}$ & $\begin{array}{l}0.65 \\
0.89 \\
0.91 \\
1.00 \\
0.91 \\
0.75 \\
1.00 \\
0.40 \\
0.75 \\
1.00 \\
1.00 \\
1.00 \\
1.00\end{array}$ & $\begin{array}{l}1.00 \\
0.99 \\
1.00 \\
1.00 \\
1.00 \\
0.88 \\
1.00 \\
0.96 \\
0.96 \\
1.00 \\
1.00 \\
1.00 \\
0.91\end{array}$ \\
\hline Endocrine, nutritional and metabolic disorders & $\begin{array}{l}\text { Morinda citrifolia } \\
\text { Lagenaria siceraria } \\
\text { Momordica charantia } \\
\text { Syzygium cuminii } \\
\text { Trigonella foenum-graecum } \\
\text { Azadirachta indica }\end{array}$ & $\begin{array}{l}0.50 \\
1.00 \\
1.00 \\
1.00 \\
1.00 \\
0.60\end{array}$ & $\begin{array}{l}0.98 \\
1.00 \\
1.00 \\
1.00 \\
1.00 \\
0.94\end{array}$ \\
\hline Disease of the neurological system & Mimosa pudica & 0.80 & 1.00 \\
\hline
\end{tabular}


http://dx.doi.org/10.4314/ajtcam.v11i6.1

Table 5 summarises the CII values in the study which ranged from 0.09 to 0.58 . Culturally important plants were Curcuma longa L, $\mathrm{CII}=0.30$; Cymbopogon nardus $\mathrm{L} . \mathrm{CII}=0.43$ and Zingiber officinale Roscoe, $\mathrm{CII}=0.42$ for category diseases of the respiratory system. Culturally important plant in the category undefined pains or illness was Chamomilla recutita having CII value of 0.56 and finally Mentha piperita with CII value of 0.58 for disease of the digestive system.

Table 5: Cultural importance index of plants with a minimum of 25 citations for an illness category.

\begin{tabular}{llc}
\hline Disease category & Species & CII \\
\hline Disease of the respiratory system & Curcuma longa & 0.30 \\
& Cymbopogon nardus & 0.43 \\
& Piper betle & 0.28 \\
& Plectranhus aromaticus & 0.23 \\
Zingiber officinale & 0.42 \\
Disease of the eye and adnea & Mangifera indica & 0.23 \\
Disease of the circulatory system & Linum usitatissimum & 0.15 \\
& Melia azedarach & 0.21 \\
Disease of the genitourinary system & Petroselinum crispum & 0.13 \\
Undefined pains or illnes & Erythroxylum laurifolium & 0.19 \\
Infectious and parasitic diseases & Chamomilla recutita & 0.56 \\
Disease of the skin and subcutaneous tissue & Allium sativum & 0.25 \\
Disease of the digestive system & Cardiospermum halicacabum & 0.23 \\
Endocrine, nutritional and metabolic disorders & Mentha piperita & 0.58 \\
Disease of the neurological system & Eupatorium triplinerve & 0.37 \\
& Pimpinella anisum & 0.47 \\
& Psidium guajava & 0.11 \\
& Illicium verum & 0.26 \\
& Ocimum tenuiflorum & 0.23 \\
& Punica granatum & 0.15 \\
& Aloe vera & 0.19 \\
Carica papaya & 0.13 \\
& Ageratum Conyzoides & 0.11 \\
& Mimosa pudica & 0.11 \\
& & 0.09 \\
\hline
\end{tabular}

CII: Cultural importance index 
Mahomoodally Afr J Tradit Complement Altern Med. (2014) 11(6):1-32 http://dx.doi.org/10.4314/ajtcam.v11i6.1

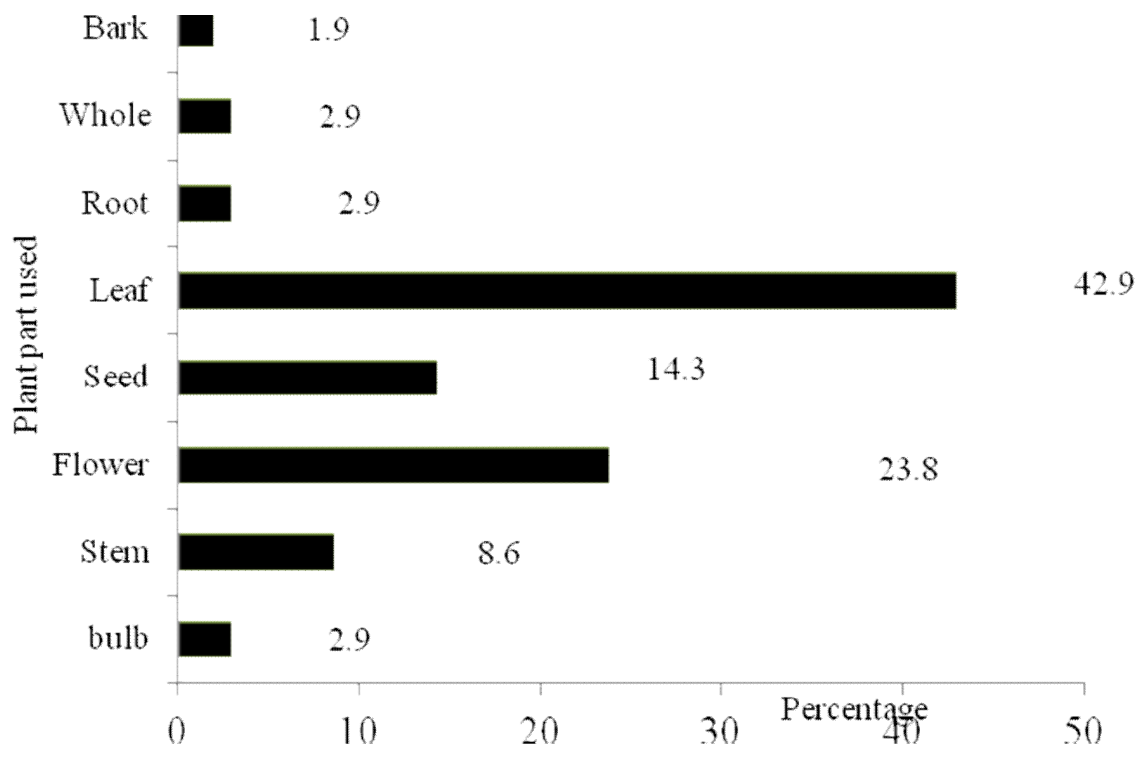

Figure 1: Plant parts used in MP preparations.

From Figure 1 it can be deduced that the majority (42.9\%) of participants made use of leaves for preparations. The next plant part that was mostly (23.8\%) employed was flowers. Barks (1.9\%), whole plants (2.9\%), roots (2.9\%) and bulbs (2.9\%) were the least used plant parts.

\section{Discussion}

In the present survey, local people were interviewed and information concerning the use of MP was gathered. Fourty five plant families have been documented in this study. Mauritius being an island that is abundant in plant resources, its population possesses an ancient tradition in the use of ethnomedicine, which is yet exploited in the treatment of minor conditions (Gurib-Fakim 2002). The uses of plants obtained were weighed against published data from other countries and it was noted that their therapeutic effect were quite similar. Plant families Fabaceae, Asteraceae, Apiaceae, Lamiaceae, and Poaceae were more popular in the present study. Among these the Asteraceae, Apiaceae and Lamiaceae family form part of some key plant families having yielded molecules of therapeutic importance. Phytochemically, the Asteraceae family is characterised by the presence of polyfructanes (especially inulin) as storage carbohydrates as opposed to polysaccharides, in the perennial taxa. The Lamiaceae family, with over 5000 species, has been one of the most significant ones in the contribution of medicinally important and culinary species. They are aromatic and have also yielded commercially important essential oils. Several species accumulate Rosmarinic acid and other derivatives of Caffeic acid. Rosmarinic acid is of pharmaceutical importance because of its non-specific complement activation and inhibition of leukotrienes (leading to an antiinflammatory effect) (Gurib-Fakim 2006).

Out of 87 MP, 3 endemic plants have been documented namely Erythroxylum laurifolium, Aphloia theiformis and Toddalia asiatica. Use of Erythroxylum laurifolium and Aphloia theiformis coincide with a previous study carried out by Neergheen et al. (2005). As far as Toddalia asiatica is concerned, its extracts have exhibited antimicrobial activity hence, validating ethnobotanical data pertaining to the plant (Narod et al., 2004). As observed in the present study, the key source of knowledge reported by the informants was normally gathered by observation and experiences and transferred to the next generation by words of mouth. This coincides with studies done by Behera et al. (2005), Longuefosse et al. (1996), Rajkumar et al. (2006) and Saikia et al. (2006).

Preparations were mainly in the form of infusions or decoctions in the current study. Hence, water was the most popular solvent that was employed. A likely explanation might be that water is a universal solvent and one that is most easily accessible as well as cheap. Interestingly it was found that infusions or decoctions of the plant's various parts are recommended for their antibacterial, antifungal, antihelminthic, anti-amoebic, antischistosomal, antimalarial, anti-inflammatory, anti-tussive, purgative activities, hypoglycemic, laxative, and cholesterol-lowering properties (Gurib-Fakim and Guého 1995). Honey was also commonly added to preparations with the view of enhancing palatability and thereby improving compliance towards therapy. A study carried out by Yineger et al. (2007) found that in most of remedy preparations, sugar, honey, tea, coffee, edible oil and garlic were the additives that were used. In the present study, various parts of plants were found to be utilised for the herbal formulations, with leaves being the most commonly used plant parts. Indeed, leaves of plants have been reported to accumulate inulins, tannins and other alkaloids (Okoegwale et al., 2001) which may be accountable for their various medicinal properties thus, explaining their wide use. Furthermore, the fact that the most frequently utilised plant parts were leaves is a more sustainable practice compared to where roots and/or the bark are used (Amri and Kisangau 2012).

Based on RFC values, it was found that Mentha piperita had the highest RFC value. RFC varies from 0 to 1 . High values of RFC designate preference and popularity of plant species for treating particular illnesses. Mentha piperita is common for its use in gastrointestinal diseases and 
http://dx.doi.org/10.4314/ajtcam.v11i6.1

studies have confirmed its antispasmodic effect of the peppermint oil on the digestive and vascular systems (Ody 2000). An analysis of the essential oil led to the identification of 20 compounds, representing 100\% of the total oil. The major constituents were menthol (49.97\%), menthone (19.08\%), methyl acetate (5.29\%), isomenthol (4.56\%) and isomenthone (4.06\%). Other representative compounds were $\varepsilon$-cariophylene (1.32\%), neo-isomenthol $(1.24 \%)$ and pulegone $(1.16 \%)$ (Sydney de Sousa et al., 2010). Mentha piperita was prepared in combination with other plants namely Pimpinella anisum, Illicium verum, Ocimum tenuiflorum and Zingiber officinale with the view of achieving better results.

In ethnobotanical studies, $\mathrm{F}_{\mathrm{IC}}$ analysis provides a measure of reliability for any given claim providing consistent proof. The product of FIC ranges from 0 to 1 . High value of FIC is indicative of agreement of selection of taxa between informants, whereas a low value indicates disagreement (Singh et al., 2012b; Ragupathy et al., 2008). A likely explanation might be that Mauritius is an island where much importance is given to family ties. Moreover, people maintain good interrelationships with neighbours and friends and thus knowledge is easily propagated. Ocimum tenuiflorum had the highest RI value and RFC value being cited for 9 different ailments that fall into 7 categories. Indeed some studies have demonstrated its (1) antioxidant activity due to flavonoids (orientin and vicenin), phenolic compounds comprising cirsilineol, cirsimaritin, isothymusin, apigenin, rosmarinic acid and appreciable quantities of eugenol, (2) antihypertensive and cardioprotective activities provided by essential fatty acids like linoleic and linolenic acids, contained in the oil produce series 1 and 3 (PGE1 and PGE3) prostaglandins and inhibit the formation of series 2 prostaglandins, and (3) antimicrobial activity supplied by the fixed oil showed good antibacterial activity against Bacillus pumilus, Pseudomonas aeruginosa and S. aureus. Higher content of linolenic acid in the fixed oil could contribute towards its antibacterial activity. Furthermore Ocimum tenuiflorum is one of the most effective adaptogen known. Its immunostimulant capacity may be responsible for the adaptogenic action of the plant (Singh et al., 2012c). Nonetheless, only few of its pharmacological properties have been mentioned here. Other plants with high RI values consisted of Allium sativum, Camellia sinensis L., Aloe vera and Zingiber officinale Roscoe. The current study recorded a large number of plants with high FL values. Most of the plants with high FL values have pharmacological effects that have been demonstrated scientifically (Koba et al., 2007; Simao da Silva et al., 2012; Ologundudu et al., 2008; Virdi et al., 2003). On the other hand, low FL, indicated less-preferred species for treating specific ailments. In contrast, these plants have been widely used against several diseases. High $\mathrm{F}_{\mathrm{IC}}$ and FLs for specific species suggest that the plants might contain valuable phytochemical compounds. These traditional medicines handed down have high $\mathrm{F}_{\mathrm{IC}}$ and FLs because of their efficacy and safety (Abe et al., 2012). Based on IAR values from the study, it was found that the lowest IAR value was for Ocimum tenuiflorum which in fact was used in the highest disease categories. High IAR values indicate that the plants species are used for a small number of disease categories compared to those having low IAR values which is indicative of use in multiple disease categories. The fact that most of the plants had high IAR values pinpoint to their specificity in treating particular disease categories. Results from the study show that according to CII index, culturally important plants were Curcuma longa L, Cymbopogon nardus and Zingiber officinale Roscoe for category diseases of the respiratory system. In the category undefined pains or illness Chamomilla recutita had highest CII value and for disease of the digestive system, Mentha piperita. High CII values of easily available plants in this study indicated the significance of availability of resources on the maintenance of knowledge over their usage (Mutheeswaran et al., 2011).

\section{Conclusion}

This study has generated a broad spectrum of information concerning common MP used by the Mauritian population. It was observed that the local population still relies to a great extent on MP. Despite the fact that several medicinal plants have been documented in this study, many still lack comprehensive phyto-therapeutic evidence. Characterising the phytochemicals responsible for the medicinally useful properties and determining their pharmacological properties might help in the discovery of new therapeutic agents.

\section{Acknowledgments}

The author is grateful to all participants and herbalists for participation in the present survey. Special thanks are extended to Ms S. Khedun, Prof. A. Gurib-Fakim, and the local botanists. The author is also grateful to the University of Mauritius.

\section{References}

1. Abbasi, A.M., Khan, M.A., and Ahmad, M. (2010). Ethnopharmacological application of medicinal plants to cure skin diseases and in folk cosmetics among the tribal communities of North-West Frontier Province, Pakistan. J. Ethnopharmacol., 128 (2): $322-335$.

2. Abe, R., and Ohtani, K. (2012). An ethnobotanical study of medicinal plants and traditional therapies on Batan Island, the Philippines. J. Ethnopharmacol., 145(2): 554-565.

3. Abouzid, S.F., and Mohamed, A.A. (2011). Survey on medicinal plants and spices used in Beni-Sueif, Upper Egypt. J. Ethnobiol Ethnomed., 7 (18): $1-6$.

4. Aburjal, T., Hudaib, M., Tayyema, R., Yousef, M., and Qishawi, M. (2006). Ethnopharmacological survey of medicinal herbs in Jordan, the Ajloun Heights region. J. Ethnopharmacol., 110 (2): 294-304.

5. Adams, J., Sibbritt, D., and Lui, C.W. (2011). The urban-rural divide in complementary and alternative medicine use: a longitudinal study of 10,638 women. BMC Complement Altern. Med., 11 (2): 1-7.

6. Adelakun, O.E., and Oyelade, O.J. (2011). Chapter 99- Chemical and antioxidant properties of Okra (Abelmoschus esculentus Moench) Seed. Nuts and Seeds in Health and Disease Prevention, 841-846.

7. Al-adhroey, A.H., Nor, Z.M., Al-Mekhlafi, H.M., Amran, A.A., and Mahmud, R. (2011). Evaluation of the use of Cocos nucifera as antimalarial remedy in Malaysian folk medicine. J. Ethnopharmacol., 134 (3): 988-991.

8. Al-Bayati, F.A. (2008). Synergistic antibacterial activity between Thymus vulgaris and Pimpinella anisum essential oils and methanol extracts. J. Ethnopharmacol., 116 (3): 403-406. 
http://dx.doi.org/10.4314/ajtcam.v11i6.1

9. Albuquerque, U.P., Lucena, R.F.P., Monteiro, J.M., Florentino, A.T.N., and Cecilia de Fatima, C.B.R.A., (2006). Evaluating two quantitative ethnobotanical techniques. Ethnobotany Res. Appl., 4: 51-60.

10. Al-Howiriny, T.A., Al-Sohaibani, M.O., El-Tahir, J.H., and Rafatullah, S. (2003). Preliminary evaluation of the anti-inflammatory and antihepatotoxic activities of 'Parsley'. J. Nat. Remedies., 3 (1): 54-62.

11. Alzweiri, M., Al-Sarhan, A., Mansi, K., Hudaid, M., and Aburjai, T. (2011). Ethnopharmacological survey of medicinal herbs in Jordan, the Northern Badia region. J. Ethnopharmacol., 137 (1): 27-35.

12. Amazu, L.U., Azikiwe, C.C.A., Njoku, C.J., Osuala, F.N., Nwosu, P.J.C., Ajugwo, A.O., and Enye, J.C. (2010). Antiinflammatory activity of the methanolic extract of the seeds of Carica papaya in experimental animals. Asian Pac. J. Trop. Med., 3 (11): 884-886.

13. Amri, E., and Kisangau, D.P. (2012). Ethnomedicinal study of plants used in villages around Kimboza forest reserve in Morogoro, Tanzania. J. Ethnobiol. Ethnomed., 8 (1): 1-9.

14. Antoun, M.D., Ramos, Z., Vazques, J., Oquendo, I., Proctor, G.R., Gerena, L., and Franzblau, S.G. (2001). Evaluation of the flora of Puerto Rico for in vitro antiplasmodial and antimycobacterial activities. Phytother. Res., 15 (7): 638-642.

15. Arambewela, L.S.R., Arawwawala, L.D.A.M., and Ratnasooriya, W.D. (2005). Antidiabetic activities of aqueous and ethanolic extracts of Piper betle leaves in rats. J. Ethnopharmacol., 102 (2): 239-245.

16. Arenal, A., Martín, L., Castillo, N., De la Torre, D., Torres, U., and González, R. (2012). Aqueous extract of Ocimum tenuiflorum decreases levels of blood glucose in induced hyperglycemic tilapia (Oreochromis niloticus). Asian Pac. J. Trop. Med., 5 (8): 634-637.

17. Au, D.T., Wu, J., Jiang, Z., Chen, H., Lu, G., and Zhao, Z. (2008). Ethnobotanical study of medicinal plants used by Hakka in Guangdong, China. J. Ethnopharmacol., 117 (1): 41-50.

18. Babu, T.D., Kuttan, G., and Padikkala, J. (1995). Cytotoxic and anti-tumour properties of certain taxa of Umbelliferae with special reference to Centella asiatica (L.) Urban. J. Ethnopharmacol., 48 (1): 53-57.

19. Bachin, R.G., and Benali, M., (2012). Antibacterial activity of the essential oils from the leaves of Eucalyptus globules against Escherichia coli and Staphylococcus aureus. Asian Pac. J. Trop. Biomed. 2 (9): 739-742.

20. Bae, M., Shin, H.S., Choi, D.W., and Shon, D.H. (2012). Antiallergic effect of Trigonella foenum-graecum L. extracts on allergic skin inflammation induced by trimellitic anhydride in BALB/c mice. J. Ethnopharmacol., 144 (3): 514-522.

21. Bakirel, T., Bakirel, U., and Keles, O.U. (2008). In vivo assessment of antidiabetic and antioxidant activities of rosemary (Rosmarinus officinalis) in alloxan-diabetic rabbits. J. Ethnopharmacol., 116 (1): 64-73.

22. Bassole, I.H.N., Lamien-Meda, A., Bayala. B., Obame, L.C., Ilboudo, A.J., Franz, C., Novak, J., Nebié, R.C., and Dicko, M.H. (2011). Chemical composition and antimicrobial activity of Cymbopogon citrates and Cymbopogon giganteus essential oils alone and in combination. Phytomed., 18 (12): 1070-1074.

23. Behera, S.K., and Mishra, M.K. (2005). Indigenous phytotherapy for genito-urinary diseases used by the Kandha tribe of Orissa, India. J. Ethnopharmacol., 102 (3): 319-325.

24. Beninca, J.P., Dalmarco, J.B., and Pizzolatti, M.G. (2011). Analysis of the anti-inflammatory properties of Rosmarinus officinalis L. in mice. Food Chem., 124 (2): 468-475.

25. Bergman, M., Varshansky, L., Gottieb, H.E., and Grossman, S. (2001). The antioxidant activity of aqueous spinach extract: chemical identification of active fractions. Phytochem., 158 (1): 143-152.

26. Bigoniya, P., Singh, C.S., and Shukla, A. (2011). Pharmacognostical and physicochemical standardisation of ethnopharmacologically important seeds of Lepidium sativum Linn. and Wrightia tinctoria R. Br. Indian J. Nat. Prod. Resour., 2 (4): 464-471.

27. Bougel, A. (2007). Prof. Ameenah Ghurib-Fakim, 2007 Laureate for her exploration and analysis of plants from Mauritius and their biomedical application [Online].Available from: http://agora.forwomeninscience.com/index.php/2007/02/2007-laureate-for-africa-and-arabstates-meet-prof-ameenah-gurib-fakim/ [Accessed $26^{\text {th }}$ August 2012].

28. Boulogne, I., Germosen-Robineau, L., Ozier-Lafontaine, H., Fleury, M., and Loranger-Merciri, G. (2011). TRAMIL ethnopharmalogical survey in Les Saintes (Guadeloupe, French West Indies): A comparative study. J. Ethnopharmacol., 133(3): 1039-1050.

29. Bum, E.N., Dawack, D.L., Schmutz, M., Rakotonirina, A., Rakotonirina, S.V., Portet, C., Jeker, A., Olpe, H.R., and Herrling, P. (2004). Anticonvulsant activity of Mimosa pudica decoction. Fitoterapia., 75 (3-4): 309-314.

30. Bussmann, R.W., and Douglas, S. (2006).Traditional medicinal plant use in Northern Peru: tracking two thousand years of healing culture. J. Ethnobiol. Ethnomed., 2 (47): 1-18.

31. Calvo, M.I., Akerreta, S., and Cavero, R.Y. (2011). Pharmaceutical ethnobotany in the Riverside of Navarra (Iberian Peninsula). J. Ethnopharmacol., 135 (1): 22-33.

32. Candrappa, S.M., Hugar, S., Itgappa, M., and Nagarajappa, K. (2009). Antidiabetic and antioxidant potential of coleus aromaticus leaf extracts in alloxan induced diabetic rats. Pharmacologyonline., 3: 1054-1064.

33. Carpinella, M.C., Herrero, G.G., Alonso, R.A., and Palacios, S. (1999). Antifungal activity of Melia azedarach fruit extract. Fitoterapia., 70 (3): 296-298.

34. Caudillo, E.R., Techante, A., and Valdivia-López, M.A. (2008). Dietary fibre content and antioxidant activity of phenolic compounds present in Mexican chia (Salvia hispanica L.) seeds. Food Chem., 107 (2): 656-663.

35. Ceuterick, M., Vandebroek, I., Torry, B., and Pieroni, A. (2008) Cross-cultural adaptation in urban ethnobotany: The Colombian folk pharmacopoeia in London. J. Ethnopharmacol., 120 (3): 342-359.

36. Chellappandian, M., Mutheeswaran, S., Pandikumar, P., Duraipandiyan, V., and Ignacimuthu, S. (2012). Quantitative ethnobotany of traditional Siddha medical practitioners from Radhapuram taluk of Tirunelveli District, Tamil Nadu, India. J. Ethnopharmacol., 143 (2): 540 547.

37. Chen, Y., Huang, B., He, J., Han, L., Zhan, Y., and Wang, Y. (2011). In vitro and in vivo antioxidant effects of the ethanolic extract of Swertia chirayita. J. Ethnopharmacol., 136 (2): 309-315.

38. Chintamunee, V., and Mahomoodally, M.F. (2012). Herbal medicine commonly used against non-communicable diseases in the tropical island of Mauritius. J. Herb. Med., 2 (4): 113-125.

39. Chokechaijaroenporn, O., Bunyapraphatsara, N., and Kongchuensin, S. (1994). Mosquito repellent activities of ocimum volatile oils. Phytomed. 1 (2): 135-139. 
http://dx.doi.org/10.4314/ajtcam.v11i6.1

40. Clark, J. (2012). Are plants used in modern medicine? [Online].Available from: http://health.howstuffworks.com/medicine/moderntechnology/plants-used-in-medicine.htm [Accessed ${ }^{\text {st }}$ Sep 2012].

41. Coelho-Ferreira, M. (2009). Medicinal knowledge and plant utilization in an Amazonian coastal community of Marudá, Pará State (Brazil). J. Ethnopharmacol., 126 (1): 159-175.

42. Courreges, M.C., Benencia, F., Coto, C.E., Massouh, E.J., and Coulombie, F.C. (1994). In vitro antiphagocytic effect of Melia azedarach leaf extracts on mouse peritoneal exudate cells. J. Ethnopharmacol., 43(2): 135-140.

43. Dallaqua, B., Saito, F.H., Rodrigues, T., Calderon, I.M., Rudge, M.V., Herrera, E., and Damasceno, D.C. (2012). Treatment with Azadirachta indica in diabetic pregnant rats: Negative effects on maternal outcome. J. Ethnopharmacol., 143 (3): 805-811.

44. Davis, R.H., Leitner, M.G., Russo, J.M., and Byrne, M.E. (1989). Oral and topical activity of Aloe vera. J. Am. Podiatr. Med. Assoc., 79 (11): 559-562.

45. DMAPR., 2012 [Online]. Available from: http://www.dmapr.org.in/ [Accessed 25 ${ }^{\text {th }}$ Sep 2012].

46. Elujoba, A.A., Odeleye O.M., and Ogunyemi, C.M. (2005). Traditional medical development for medical and dental primary health care delivery system in Africa. Afr. J. Trad. Compl. Alter. Med., 2 (1): 46-61.

47. El-Shemy, H.A., Aboul-Soud, M.A., Nassr-Allah, A.A., Aboul-Enein, K.M., Kabash, A., and Yagi, A. (2010). Antitumor properties and modulation of antioxidant enzymes' activity by Aloe vera leaf active principles isolated via supercritical carbon dioxide extraction. Curr. Med. Chem., 17 (2): 129-38.

48. Ferreira, I.C.F.R., Barros. L., Soares, M.E., Bastos, M.L., and Pereira, J.A. (2007). Antioxidant activity and phenolic contents of Olea europaea L. leaves sprayed with different copper formulations. Food Chem., 103 (1): 188-195.

49. Fleer, H., and Verspohl, E.J. (2007). Antispasmodic activity of an extract from Plantago lanceolata L. and some isolated compounds. Phytomed.14 (6): 409-415.

50. Gachet, M.S., Lecaro, J.S., Kaiser, M., Brun, R., Navarette, H., Munoz, R.A., Bauer, R., and Schühly, W. (2010). Assessment of antiprotozoal activity of plants traditionally used in Ecuador in the treatment of leishmaniasis. J. Ethnopharmacol., 128 (1): 184-197.

51. Gbolade, A.A. (2009). Inventory of antidiabetic plants in selected districts of Lagos State, Nigeria. J. Ethnopharmacol., 121 (1): $135-139$.

52. Ghule, A.E., Jadhav, S.S., Bodhankar, S.L., 2012. Effect of ethanolic extract of seeds of Linum usitatissimum (Linn.) in hyperglycaemia associated ROS production in PBMNCs and pancreatic tissue of alloxan induced diabetic rats. Asian. Pac. J. Trop. Dis., 2 (5): 405-410.

53. Gouveia, S.C., and Castilho, P.C. (2012). Phenolic composition and antioxidant capacity of cultivated artichoke, Madeira cardoon and artichoke-based dietary supplements. Food Res. Int., 48 (2): 712-724.

54. Gulcin, I., Oktay, M., Kirecci, E.,_and Küfrevığlu, O.I. (2003). Screening of antioxidant and antimicrobial activities of anise (Pimpinella anisum L.) seed extracts. Food Chem., 83 (3): 371-382.

55. Gurib-Fakim, A., and Guého J. (1995). Plantes médicinales de Maurice. Edition de l'Ocean Indien. Mauritius (Tome 2).

56. Gurib-Fakim, A. (2002). Mauritius through its medicinal plants towards a better understanding of medicinal plants Of the Indian Ocean Islands. Edition Le Printemps. Mauritius.

57. Gurib-Fakim, A. (2006) Medicinal plants: Traditions of yesterday and drugs of tomorrow. Mol Aspects Med., 27 (1): 1-93.

58. Habiboallah, G., Nasroallah, S., Mahdi, Z., Nasser, M.S., Massoud, Z., Ehsan, B.N., Mina, Z.J., and Heidar, P. (2008). Histological evaluation of Curcuma longa-ghee formulation and hyaluronic acid on gingival healing in dog. J. Ethnopharmacol., 120 (3): 335-341.

59. Hajdu, Z., and Hohmann, J. (2012). An ethnopharmacological survey of the traditional medicine utilized in the community of Porvenir, Bajo Paraguá Indian Reservation, Bolivia. J. Ethnopharmacol., 139 (3): 838-857.

60. Hamid, A.A., Shah, Z.M., and Muse, R. (2002). Characterisation of antioxidative activities of various extracts of Centella asiatica (L) Urban. Food Chem., 77 (4): 465-469.

61. Hamza, A.A. (2010). Ameliorative effects of Moringa oleifera Lam seed extract on liver fibrosis in rats. Food Chem. Toxicol., 48 (1): $345-$ 355 .

62. Hamza, N., Berke, B., Cheze, C., Le Garrec, R., Umar, A., Agli,A.N., Lassalle, R., Jové, J., Gin, H., and Moore, N. (2012). Preventive and curative effect of Trigonella foenum-graecum L. seeds in C57BL/6J models of type 2 diabetes induced by high-fat diet. J. Ethnopharmacol., 142 (2): 516-522.

63. Hansen, K., Adsersen, A., Smitt, U.W., Nyman, U., Christensen, S.B., Schwartner, C., and Wagner, H. (1996). Angiotensin converting enzyme (ACE) inhibitory flavonoids from Erythroxylum laurifolium. Phytomed., 2 (4): 313-317.

64. Harel, D., Khalid, S.A., Kaiser, M., Brun, R., Wunsch, B., and Schmidt, T.J. (2011). Encecalol angelate, an unstable chromene from Ageratum conyzoides L.: Total synthesis and investigation of its antiprotozoal activity. J. Ethnopharmacol., 137 (1): 620-625.

65. Harris, J.C., Cottrell, S., Plummer, S., and Lloyd, D. (2001). Antimicrobial properties of Allium sativum (garlic). Appl. Microbiol. Biotechnol., 57 (3): 282-286.

66. Herchi, W., Harrabi, S., Sebei, K., Rochut, S., Boukhchina, S., Pepe, C., and Kallele, H. (2009). Phytosterols accumulation in the seeds of Linum usitatissimum L. Plant Physiol. Biochem., 47 (10): 880-885.

67. Holroyd, E., Zhang, A.L., Suen, L.K.P., and Xue, C.C.L. (2008). Beliefs and attitudes towards complementary medicine among registered nurses in Hong Kong. Int. J. Nurs. Stud., 45 (11): 1660-1666.

68. Huang, M.H., Huang, S.S., Wang, B.S., Wu, C.H., Sheu, M.J., Hou, W.C., Lin, S.S., and Huang, G.H. (2011). Antioxidant and antiinflammatory properties of Cardiospermum halicacabum and its reference compounds ex vivo and in vivo. J. Ethnopharmacol., 133 (2): 743 750.

69. Hudson, T. (2008). Maca: new insights on an ancient plant. Integr Med., 7 (6): 54-57.

70. Hussein, A., Sonkar, A.K., Ahmad, P., and Wahab, S. (2012). In-vitro anthelmintic activity of Coleus aromaticus root in Indian Adult Earthworm. Asian Pac. J. Trop. Dis., 2 (1): 425-427.

71. Jagtap, U.B., Waghmare, S.R., Lokhande, V.H., Suprasanna, P., Bapat, V.A. (2011). Preparation and evaluation of antioxidant capacity of Jackfruit (Artocarpus heterophyllus Lam.) wine and its protective role against radiation induced DNA damage. Ind. Crop. Pro., 34 (3): $1595-$ 1601.

72. Jagtap, U.B., and Bapat, V.A. (2010). Artocarpus: A review of its traditional uses, phytochemistry and pharmacology. J. Ethnopharmacol., 129 (2): 142-166. 
http://dx.doi.org/10.4314/ajtcam.v11i6.1

73. Jaric, S., Mitrovic, M., Djurdjevic, L., Kostić, O., Gajić, G., Pavlović, D., and Pavlović, P. (2011). Phytotherapy in medieval Serbian medicine according to the pharmacological manuscripts of the Chilandar Medical Codex (15-16th centuries). J. Ethnopharmacol., 137 (1): 601-619.

74. Jasso De Rodríguez, D., Hernández-Castillo, D., Rodríguez-García, R., and Angulo-Sanchez, J.L. (2005). Antifungal activity in vitro of Aloe vera pulp and liquid fraction against plant pathogenic fungi, Ind. Crop. Pro., 21 (1): 81-87.

75. Jonville, M.C., Kodja, H., Strasberg, D., Pichette, A., Ollivier, E., Frédérich, M., Angenot, L., and Legault, J. (2011). Antiplasmodial, antiinflammatory and cytotoxic activities of various plant extracts from the Mascarene Archipelago. J. Ethnopharmacol., 136 (3): 525-531.

76. Juntachote, T., and Berghofer, E. (2005). Antioxidative properties and stability of ethanolic extracts of Holy basil and Galangal. Food Chem., 92 (2): 193-202.

77. Kaisoon, O., Konczak, I., and Siriamornpun, S. (2011). Potential health enhancing properties of edible flowers from Thailand. Food Res. Int., 46 (2): 563-571.

78. Kaou, A.M., Mahiou-Leddet, V.,Hutter, S., Aïnouddine, S., Hassani, S., Yahaya, I., Azas. N., and Ollivier, E. (2008). Antimalarial activity of crude extracts from nine African medicinal plants. J. Ethnopharmacol., 116 (1): 74-83.

79. Kim, K., Kim, H., Kwon., J., Lee, S., Kong, H., Im, S.A., Lee, Y.H., Lee, Y.R., Oh S.T., Jo, T.H., Park Y.I., Lee C.K., and Kim, K. (2009). Hypoglycemic and hypolipidemic effects of processed Aloe vera gel in a mouse model of noninsulin-dependent diabetes mellitus. Phytomed., 16 (9): 856-63.

80. Kirtikar, K.R., and Basum, B.D. (1935). Indian Medicinal Plants. (1-4). Allahabad. India: Lalit Mohan Basu.

81. Koba, K., Garde, D., Sanda, K., Raynaud, C., and Chaumont, J.P. (2007). Chemical composition and antimicrobial properties of the leaf essential oil of Coleus aromaticus Benth from Cambodia. Int. J. Essen. Oil Ther., 1 (1): 16-20.

82. Kokane, D.D., More, R.Y., Kale, M.B., Nehete, M.N., Mehendale, P.C., and Gadgoli, C.H.,(2009). Evaluation of wound healing activity of root of Mimosa pudica. . J. Ethnopharmacol., 124 (2): 311-315.

83. Komutarin, T., Azadi, S., Butterworth, L., Keil, D., Chitsomboon, B., Suttajit, M., and Meade B.J. (2004). Extract of the seed coat of Tamarindus indica inhibits nitric oxide production by murine macrophages in vitro and in vivo. Food Chem. Toxicol., 42 (4): $649-658$.

84. Kreydiyyeh, S. I., Usta, J., Kaouk, I., and Al-Sadi, R. (2001). The mechanism underlying the laxative properties of Parsley extract. Phytomed., 8 (5): 382-388.

85. Kumar, D., Kumar, A., and Prakash, O. (2012A). Potential antifertility agents from plants: A comprehensive review. J. Ethnopharmacol., 140 (1): $1-32$.

86. Kumar, D., Arya, V., Kaur, R., Bhat, Z.A., Gupta, V.K., and Kumar, V. (2012B). A review of immunomodulators in the Indian traditional health care system. J. Microbiol. Immunol. Infect., 45 (3): 165-184.

87. Langmead, L., Makins, R.J., and Rampton, D.S. (2004). Antiinflammatory effects of Aloe vera gel in human colorectal mucosa in vitro. Aliment. Pharmacol. Ther., 19 (5): 521-7.

88. Lentz, A.C., Carsoniii, C.C., and Marson, L. (2006). Does the new herbal supplement maca enhance erectile function or female sexual function? Semin. Prev. Altern. Med., 2 (2): 85-90.

89. Liu, C., Xue, Y., Ye, Y., Yuan, F., Liu, J., and Shuang, J. (2007). Extraction and Characterization of Antioxidant Compositions from Fermented Fruit Juice of Morinda citrifolia (Noni). Agric. Sci. China., 6 (12):1494-1501.

90. Loggia, R.D., Traversa, U., Scarcia, V., and Tubaro, A. (1982). Depressive effects of Chamomilla recutita (L.) Rausch, tubular flowers, on central nervous system in mice. Pharmacol. Res. Commun., 14 (2): 153-162.

91. Loi, B., Fantini, N., Colombo, G., Gessa, G.L., Riva, A., Bombardelli, E., Morazzoni, P., and Carai, M.A. (2013). Reducing effect of an extract of Phaseolus vulgaris on food intake in mice - Focus on highly palatable foods. Fitoterapia., 85: 14-19.

92. Longuefosse, J.L., and Nossin, E. (1996). Medical ethnobotany survey in Martinique. J. Ethnopharmacol., 53 (3): 117-142.

93. Machado, D.G., Cunha, M.P., Neis, V.B., Balen,G.O., Colla, A.R., Grando, J., Brocardo, P.S., Bettio, L.E., Dalmarco, J.B., Rial, D., Prediger, R.D., Pizzolatti, M.G., and Rodrigues, A.L. (2012). Rosmarinus officinalis L. hydroalcoholic extract, similar to fluoxetine, reverses depressive-like behavior without altering learning deficit in olfactory bulbectomized mice. J. Ethnopharmacol., 143 (1): 158-169.

94. Mahattanadul, S., Ridtitid, W., Nima, S., Phdoongsombut, N., Ratanasuwon, P., and Kasiwong, S. (2011). Effects of Morinda citrifolia aqueous fruit extract and its biomarker scopoletin on reflux esophagitis and gastric ulcer in rats. J. Ethnopharmacol., 134 (2): $243-250$.

95. Mahendra, P., and Bisht, S. (2011). Anti-anxiety activity of Coriandrum sativum assessed using different experimental anxiety models. Indian J Pharmaco., 43 (5): 574-577.

96. Maiti, R., Jana, D., Das, U.K., and Ghosh, D. (2004). Antidiabetic effect of aqueous extract of seed of Tamarindus indica in streptozotocininduced diabetic rats. J. Ethnopharmacol., 92 (1): 85-91.

97. Mandal, S.C., Kumar, C.K.A., Majumder, A., Majumder, R., and Maity, B.C. (2000). Antibacterial activity of Litsea glutinosa bark. Fitoterapia., 71(4): 439-441.

98. Maregesi, S.M., Pieters, L., Ngassapa, O.D., Vingerhoets, R., Cos, P., Berghe, D.A., and Vlietinck, A.J. (2008). Screening of some Tanzanian medicinal plants from Bunda district for antibacterial, antifungal and antiviral activities. J. Ethnopharmacol., 119 (1): $58-66$.

99. Marnewick, J.L., Van Der Westhuizen, F.H., Joubert, E., Swanevelder, S., Swart, P., and Gelderblom, W.C. (2008). Chemoprotective properties of rooibos (Aspalathus linearis), honeybush (Cyclopia intermedia) herbal and green and black (Camellia sinensis) teas against cancer promotion induced by fumonisin B1 in rat liver. Food Chem. Toxicol., 47 (1): 220-229.

100. Martinez, O.R., Osomo, O.R., and Gomez, C. (2011). Spasmolytic activity of Rosmarinus officinalis L. involves calcium channels in the guinea pig ileum. J. Ethnopharmacol., 137 (3): 1528-1532.

101. Mathew, S., and Abraham, T.E. (2006). In vitro antioxidant activity and scavenging effects of Cinnamomum verum leaf extract assayed by different methodologies. Food Chem. Toxicol., 44 (2): 198-206.

102. Mayakrishnan, V., Veluswamy, S., Sundaram, K.S., Kannappan, P., and Abdullah, N. (2013). Free radical scavenging potential of Lagenaria siceraria (Molina) Standl fruits extract. Asian Pac. J. Trop. Med., 6 (1): 20-26.

103. Moazedi, A.A., Mirzaie, D.N., Seyyednejad, S.M., Zadkarami, M.R., Amirzargar, A. (2007). Spasmolytic effect of Petroselinum crispum (Parsley) on rat's ileum at different calcium chloride concentrations. Pak. J. Biol. Sci., 10 (22): 4036-42. 
http://dx.doi.org/10.4314/ajtcam.v11i6.1

104. Moyo, B., Oyedemi, S., Masika, P.J., and Muchenje, V. (2012). Polyphenolic content and antioxidant properties of Moringa oleifera leaf extracts and enzymatic activity of liver from goats supplemented with Moringa oleifera leaves/sunflower seed cake. Meat Sci., 91 (4): $441-$ 447.

105. Mukherjee, A., and Roy, S.D. (1987). An account of Piperaceae and Saururaceae in the hills of Darjeeling district, West Bengal. J. Econ. Taxonomy Botany., 9: 367-372.

106. Muniappan, A., and Pandurangan, S. (2012). Syzygium cumini (L.) Skeels: A review of its phytochemical constituents and traditional uses. Asian Pac. J. Trop. Biomed., 2 (3): 240-246.

107. Murali, R., and Saravanan, R. (2012). Antidiabetic effect of D-limonene, a monoterpene in streptozotocin-induced diabetic rats. Biomed. Prev. Nutr., 2. (4): 269-275.

108. Murti, K., Panchal, M.A., Gajera, V., and Solanki, J. (2013). Pharmacological properties of Matricaria recutita: A review. Pharmacologia, 3 (8): 348-351.

109. Mutheeswaran, S., Pandikumar, P., Chellappandian, M., and Ignacimuthu, S. (2011). Documentation and quantitative analysis of the local knowledge on medicinal plants among traditional Siddha healers in Virudhunagar district of Tamil Nadu, India. J. Ethnopharmacol., 137 (10): 523-533.

110. Muzitano, M.F., Bergonzi, M.C., De Melo, G.O., Lage, C.L., Bilia, A.R., Vincieri, F.F., Rossi-Bergmann,B., and Costa, S.S. (2011). Influence of cultivation conditions, season of collection and extraction method on the content of antileishmanial flavonoids from Kalanchoe pinnata. J. Ethnopharmacol., 133 (1): 132-137.

111. Nadeem, S., Dhore, P., Quazi, M., Pawar, S., and Raj, N., (2012). Lagenaria siceraria fruit extract ameliorate fat amassment and serum TNF-in high-fat diet-induced obese rats. Asian Pac. J. Trop. Med., 5 (9): 698-702.

112. Namsa, N.D., Tag, H., Mandal, M., Kalita, P., and Das, A.K., (2009). An ethnobotanical study of traditional anti-inflammatory plants used by the Lohit community of Arunachal Pradesh, India. J. Ethnopharmacol., 125 (2): 234-245.

113. Namukobe, J., Kasenene, J.M., Kiremire, B.T., Byamukama, R., Kamatenesi-Mugisha, M., Krief, S., Dumontet, V., and Kabasa, J.D. (2011). Traditional plants used for medicinal purposes by local communities around the Northern sector of Kibale National Park, Uganda. J. Ethnopharmacol., 136 (1): 236-245.

114. Narod, F.B., Gurib-Fakim, A., and Subratty, A.H. (2004). Biological investigations into Antidesma madagascariense Lam. (Euphorbiaceae), Faujasiopsis flexuosa (Lam.) C. Jeffrey (Asteraceae), Toddalia asiatica (L.) Lam. and Vepris lanceolata (Lam.) G. Don (Rutaceae). Cell. Mol. Biol., 3: 15-21.

115. Neergheen, V.S., Bahorun, T., Soobrattee, M.A., and Aruoma, O.I. (2005). A Survey Of The Mauritian Endemic Flora For Potential Prophylaxis Food and Agricultural Research Council, Réduit, Mauritius. [Online]. Available from :http://www.gov.mu/portal/sites/ncb/moa/farc/amas2005/pdf/S01.1.pdf [Accessed 1st January 2013].

116. Newton, S.M., Lau, C.,Gurcha, S.S., Besra, G.S., and Wright, C.W. (2002). The evaluation of forty-three plant species for in vitro antimycobacterial activities: isolation of active constituents from Psoralea corylifolia and Sanguinaria canadensis. J. Ethnopharmacol., 79 (1): 57-67.

117. Nweze, N.E., and Obiwulu, I.S. (2009). Anticoccidial effects of Ageratum conyzoides. J. Ethnopharmacol., 122 (1): 6-9.

118. Ody, P. (2000). O guia completo das plantas medicinais. $1^{\text {st }}$ ed. Portugal: Dorling Kindersley/Civilizacão.

119. Okoegwale, E.E., and Omefezi, J.U. (2001). Some herbal preparations among the people of Isoko Clan of Delta State, Nigeria. J. Appl. Sci., 4: $2350-2371$

120. Ologundudu, A., Lawal, A.O., Ololade, I.A., Omonkhua, A.A., and Obi, F.O. (2008). The anti-ulcerogenic activity of aqueous extract of carica papaya fruit on aspirin - induced ulcer in rats. The Inter. J. Toxico., 5 (2). [Online]. Available from: http://ispub.com/IJTO/5/2/4180

121. Ordoñez, A.A.L., Gomez, J.D., Vattuone, M.A., and Isla, M.I., (2006). Antioxidant activities of Sechium edule (Jacq.) Swartz extracts. Food Chem., 97 (3): 452-458.

122. Orwa, J.A., Jondiko, I.J.O., and Minja, R.J.A. (2008). The use of Toddalia asiatica (L) Lam. (Rutaceae) in traditional medicine practice in East Africa. J. Ethnopharmacol., 115 (2): 257-262.

123. Otsuki, N., Dang N.H., Kumagai, E., Kondo, A., Iwata, S., and Morimoto, C. (2010). Aqueous extract of Carica papaya leaves exhibits antitumor activity and immunomodulatory effects. J. Ethnopharmacol., 127 (3): 760-767.

124. Ozsoy-Sacana, O., Yanardag, R., Orak, H., Ozgey, Y., Yarat, A., and Tunali, T. (2006). Effects of parsley (Petroselinum crispum) extract versus glibornuride on the liver of streptozotocin-induced diabetic rats. J. Ethnopharmacol., 104 (1-2): 175-181.

125. Palani, S., Raja, S., Naresh, R., and Kumar, B.S. (2010). Evaluation of nephroprotective, diuretic and antioxidant activities of Plectranthus amboinicus on acetaminophen-induced nephrotoxic rats. Toxicol. Mech. Methods., 20 (4): 213-21.

126. Panahi, Y., Akhavan, A., Sahebkar, A., Hosseini, S.M., Taghizadeh, M., Akbari, H., Sharif, M.R., and Imani, S. (2012). Investigation of the effectiveness of Syzygium aromaticum, Lavandula angustifolia and Geranium robertianum essential oils in the treatment of acute external otitis: A comparative trial with ciprofloxacin. J. Microbiol. Immunol. Infect. [Online] Available from: http://dx.doi.org/10.1016/j.jmii.2012.10.002[Accessed 23th Dec 2012].

127. Pandikumar, P., Chellappandian, M., and Mutheeswaran, S. (2011). Consensus of local knowledge on medicinal plants among traditional healers in Mayiladumparai block of Theni District, Tamil Nadu, India. J. Ethnopharmacol., 134 (2): 354-362.

128. Paulino De Albuquerque, U., Muniz De Medeiros, P., Almeida, A.L., Monteiro, J.M., Neto, E.M.L., Gomes De Melo, J., and Santos, J.P.(2007). Medicinal plants of the caatinga (semi-arid) vegetation of NE Brazil: A quantitative approach. J. Ethnopharmacol., 114 (3): $325-$ 354.

129. Polio, A., Natale, A.D., and Appetiti, E. (2008). Continuity and change in the Mediterranean medical tradition: Ruta spp. (rutaceae) in Hippocratic medicine and present practices. J. Ethnopharmacol., 116 (3): 469-482.

130. Prasad, P.N., and Abraham, Z. (1984). Ethnobotany of Nayadis of North Kerala. Journal of Economic Taxonomy and Botany, 5: 41-48.

131. Ragupathy, S., Newsmaster, S.G., Murugesan, M., Velusamy, B., Ul-Huda, M.M. (2008). Consesensus of the Malasars traditional knowledge of medicinal plants in the Velliengiriholi hills India. J. Ethnobiol. Ethnomed., 4 (8):1-14.

132. Rajkumar, N., and Shivanna, M.B. (2006). Traditional herbal medicinal knowledge in Sagar taluk of Shimoga district, Karnataka, India. Indian J. Nat. Prod. Re., 1 (1): 102-108. 
http://dx.doi.org/10.4314/ajtcam.v11i6.1

133. Rajkumar, N., and Shivanna, M.B. (2009). Ethno-medicinal application of plants in the eastern region of Shimoga district, Karnataka, India. J. Ethnopharmacol., 126 (1): 64-73.

134. Rangasamy, O., Raoelison, G., Rakotoniriana, F.E., Cheuk, K., Urverg-Ratsimamanga, S., Quetin-Leclercq, J., Gurib-Fakim, A., and Subratty, A.H. (2007). Screening for anti-infective properties of several medicinal plants of the Mauritians flora. J. Ethnopharmacol., 109 (2): 331-337.

135. Ratnasooriya, W.D., and Fernado, T.S.P. (2008). Effect of black tea brew of Camellia sinensis on sexual competence of male rats. J. Ethnopharmacol., 118 (3): 373-377.

136. Rokaya, M.B., Munzbergova, Z., and Timsina, B. (2010). Ethnobotanical study of medicinal plants from the Humla district of western Nepal. J. Ethnopharmacol., 130 (3): 485-504.

137. Saikia, A.P., Ryakala, V.K., Sharma, P., Goswami, P., and Bora, U. (2006). Ethnobotany of medicinal plants used by Assamese people for various skin ailments and cosmetics. J. Ethnopharmacol., 106 (2): 149-57.

138. Sandoval, M., Okuhama, N.N., Angeles, F.M., Melchor, V.V.,Condezo, L.A., Lao, and Miller, M.J.S. (2002). Antioxidant activity of the cruciferous vegetable Maca (Lepidium meyenii). Food Chemi., 79 (2): 207-213.

139. Satheeshkumar, N., Mukherjee, P.K., Bhadra, S., and Saha. B.P. (2010). Acetylcholinesterase enzyme inhibitory potential of standardized extract of Trigonella foenum graecum L and its constituents. Phytomed., 17 (3-4): 292-295.

140. Saxena, R., Singh, R., and Kumar, P., Singh Negi, M.P., Saxena, V.S., Geetharani, P., and Allan, J.J. (2012). Efficacy of an Extract of Ocimum tenuiflorum (OciBest) in the Management of General Stress: A Double-Blind, Placebo-Controlled Study [Online]. Evid. Based Complement. Alternat. Med., Available from: http://www.hindawi.com/journals/ecam/2012/894509/ [Accessed on 28 ${ }^{\text {th }}$ Nov 2012].

141. Scheffler, A., Rauwald, H.W., Kampa, B., Mann, U., Mohr, F.W., Dhein, S. (2008). Olea europaea leaf extract exerts L-type Ca ${ }^{2+}$ channel antagonistic effects. J. Ethnopharmacol., 120 (2): 233-240.

142. Sermakkani, M., and Thangapandian, V. (2011). Studies on preliminary phytochemical constituents and antimicrobial activity of Ocimum tenuiflorum l. leaves. Intern J of Institutional Pharm and Life Sci, 1 (1): 1-12.

143. Simao Da Silva, K.A.B., Klein- Junior, L.C., Cruz, S.M., Caceres, A., Quintão, N.L.M., Monache, F.D., and Cechinel-Filho, V. (2012). Antiinflammatory and anti-hyperalgesic evaluation of the condiment laurel (Litsea guatemalensis Mez.) and its chemical composition. Food Chem., 132 (4), 1980-1986.

144. Singh, R., Shushni, M.A.M., and Belkheir, A. (2011). Antibacterial and antioxidant activities of Mentha piperita L. Arabian J. Chem., [online].Available from: http://dx.doi.org/10.1016/j.arabjc.2011.01.019 [Accessed 25th Nov 2012].

145. Singh, A.G., Kumar, A., Tewari, D.D. (2012B). An ethnobotanical survey of medicinal plants used in Terai forest of western Nepal. J. Ethnobiol. Ethnomed., 8 (19): 1-15.

146. Singh, N., Verma, P., Pandey, R. (2012A). Therapeutic potential of organic Triticum aestivum Linn. (Wheat Grass) in prevention and treatment of chronic diseases: An Overview. Intern J Pharmaceut Sci and Drug Res, 4(1): 10-14.

147. Singh, E., Sharma, S., Dwivedi, J., and Sharma, S. (2012C). Diversified potentials of Ocimum sanctum Linn (Tulsi): An exhaustive survey. J. Nat. Prod. Plant Resour., 2 (1), 39-48.

148. Singhal, K.G., and Gupta, G.D. (2012). Hepatoprotective and antioxidant activity of methanolic extract of flowers of Nerium oleander against $\mathrm{CCl}_{4}$-induced liver injury in rats. Asian Pac. J. Trop. Med., 5 (9): 677-685.

149. Snezana, S. (2007). Anti-genotoxic effect of aloe vera gel on the mutagenic action of ethyl methanesulfonate. Arch. Biol. Sci., 59 (3): 223226.

150. Srivastava, J., and Vankar, P.S. (2012). Antioxidant profile in north eastern India: traditional herbs. NFS., 42 (1): $26-33$.

151. Ssegawa, P., and Kasenene, J.M. (2007). Medicinal plant diversity and uses in the Sango bay area, Southern Uganda. J. Ethnopharmacol., 113 (3): 521-540.

152. Sun, Z., Chen, J., Ma, J. Jiang, Y., Wang, M., Ren, G., and Chen, F. (2012). Cynarin-rich sunflower (Helianthus annuus) sprouts possess both antiglycative and antioxidant activities. J. Agric. Food. Chem., 60 (12): 3260-3265.

153. Sung, Y., Kim, Y.S., and Kim, H.K. (2012). Illicium verum extract inhibits TNF- $\alpha$ - and IFN- $\gamma$-induced expression of chemokines and cytokines in human keratinocytes. J. Ethnopharmacol., 144 (1): 182-189.

154. Sussman, L.K. (1980). Herbal medicine of Mauritius. J. Ethnopharmacol., 2 (3): 259-278.

155. Sydney De Sousa, A.A., Soares, P.M.G., Saldanha De Almeida, A.N., Maia, A.R., Prata De Souza, E., and Assreuy, A.M.S. (2010). Antispasmodic effect of Mentha piperita essential oil on tracheal smooth muscle of rats. J. Ethnopharmacol., 130 (2): $433-436$.

156. Tardío, J., and Pardo-De-Santayana, M. (2008). Cultural importance indices: a comparative analysis based on the useful wild plants of Southern Cantabria (Northern Spain). Econ. Bot., 62 (1): 24-39.

157. Tavare, A.C., Goncalves, M.J., Cavaleiro, C., Cruz, M.T., Lopes, M.C., Canhoto, J., and Salgueiro, L.R. (2008). Essential oil of Daucus carota subsp. halophilus: Composition, antifungal activity and cytotoxicity. J. Ethnopharmacol., 119 (1): $129-134$.

158. Tembhurne, S.V., and Sakarkar, D.M. (2012). Anti-obesity and hypoglycemic effect of ethanolic extract of Murraya koenigii (L) leaves in high fatty diet rats. Asian Pac J Trop Dis., 2 (1): 166-168.

159. Tenore, G.C., Troisi, J., Di Flore, R., Basile, A., and Novellino, E. (2012). Chemical composition, antioxidant and antimicrobial properties of Rapa Catozza Napoletana (Brassica rapa L. var. rapa DC.) seed meal, a promising protein source of Campania region (southern Italy) horticultural germplasm. J. Sci. Food Agric., 92 (8): 1716-24.

160. Thakurta, P., Bhowmik, P., Mukherjee, S., Hajra, T.K., Patra, A., and Bag, P.K. (2007). Antibacterial, antisecretory and antihemorrhagic activity of Azadirachta indica used to treat cholera and diarrhea in India. J Ethnopharmacol., 111 (3): $607-612$.

161. Tirapelli, C.R., Andrade, C.R., Cassano, A.O., De Souza, F.A., Ambrosio, S.R., Da Costa, F.B., and De Oliveira, A.M. (2007). Antispasmodic and relaxant effects of the hidroalcoholic extract of Pimpinella anisum (Apiaceae) on rat anococcygeus smooth muscle. J. Ethnopharmacol., 110 (1): 23-29.

162. Trotter, R., and Logan, M., (ED). (1986). Informant consensus: a new approach for identifying potentially effective medicinal plants. In Plants in indigenous medicine and diet: biobehavioural approaches. Redgrave Publishers. New York: 91-112.

163. Tzeng, T.F., Lu, H.J., Liou, S.S., Chang, C.J., and Liu, I.M. (2013). Reduction of lipid accumulation in white adipose tissues by Cassia tora (Leguminosae) seed extract is associated with AMPK activation. Food Chem., 136 (2): 1086-1094. 
http://dx.doi.org/10.4314/ajtcam.v11i6.1

164. Vankar, P.S., and Srivastava, J. (2012). Principal phenolic phytochemicals and antioxidant property in Eucalyptus bark. NFS., 42(6): 412-421

165. Vinod, V., Tiwari, P.K., and Meshram, G.P. (2011). Evaluation of mutagenic and antimutagenic activities of neem (Azadirachta indica) seed oil in the in vitro Ames Salmonella/microsome assay and in vivo mouse bone marrow micronucleus test. J. Ethnopharmacol., 134(3): 931-937.

166. Virdi, J., Sivakami,S., Shahani, S., Suthar, A.C., Banavalikar, M.M., and Biyani, M.K., (2003). Antihyperglycemic effects of three extracts from Momordica charantia. J. Ethnopharmacol., 88 (1): 107-111.

167. Wachsman, M.B., Damonte, E.B., Coto, C.E., and De Torres, R.A. (1987). Antiviral effects of Melia azedarach L. leaves extracts on Sindbis virus-infected cells. Antiviral Res., 8 (1): 1-12.

168. Wang, G., Hu, W., Huang, B., and Qin, L. (2011). Illicium verum: A review on its botany, traditional use, chemistry and pharmacology. J. Ethnopharmacol., 136 (1): 10-20.

169. Wodah, D., and Asase, A. (2012). Ethnopharmacological use of plants by Sisala traditional healers in northwest Ghana. Pharm. Biol., 50 (7): 807-15.

170. Wong, P., and Kitts, D. (2006). Studies on the dual antioxidant and antibacterial properties of parsley (Petroselinum crispum) and cilantro (Coriandrum sativum) extracts. Food Chem., 97 (3): 505-515.

171. Wu, C.H., and Yen, G.C. (2004). Antigenotoxic properties of Cassia tea (Cassia tora L.): Mechanism of action and the influence of roasting process. Life Sci., 76 (1): 85-101.

172. Xia, X., Cheng, G., Pan, Y., Xia, Z.H., and Kong, L.D. (2007). Behavioral, neurochemical and neuroendocrine effects of the ethanolic extract from Curcuma longa L. in the mouse forced swimming test. J. Ethnopharmacol., 110 (2): 356-363.

173. Yadav, R.N.S., and Agarwala, M. (2011). Phytochemical analysis of some medicinal plants. J. Phytol., 3 (12): 10-14.

174. Yanzuko, H., Ahmed, Q.U., Santosa, R.I., Akter, S.F., and Talib, N.A. (2011). Beneficial effect of the leaves of Murraya koenigii (Linn.) Spreng (Rutaceae) on diabetes-induced renal damage in vivo. J. Ethnopharmacol., 135(1): 88-94.

175. Yazdanparast, R., Bahramikia, S., and Ardestani, A. (2008). Nasturtium officinale reduces oxidative stress and enhances antioxidant capacity in hypercholesterolaemic rats. Chem. Biol. Interact., 172 (3): 176-184.

176. Yineger, H., and Yewhalaw, D. (2007). Traditional medicinal plant knowledge and use by local healers in Sekoru District, Jimma Zone, Southwestern Ethiopia. J. Ethnobiol. Ethnomed., 3 (24): 1-7.

177. Yusuf, S., Agunu, A., and Mshelia, D. (2004). The effect of Aloe vera A. Berger (Liliaceae) on gastric acid secretion and acute gastric mucosal injury in rats, J. Ethnopharmacol., 93 (1), 33-37.

178. Zheng, X., and Xing, F. (2009). Ethnobotanical study on medicinal plants around Mt.Yinggeling, Hainan Island, China. J. Ethnopharmacol., 124 (2): 197-210. 